\title{
البدائل المقترحة للتركيب المحصولي الثتتوي لسد الفجوة من أهم المحاصيل الاستراتيجية في مصر
}

\author{
غادة صالح حسن ، صفاء محمد الوكيل \\ معهد بحوث الإقتصاد الزراعي - مركز البحوث الزراعية
}

Received: Jul. 31,2017

Accepted: Aug. 16, 2017

الملخص:

بالرغم من زيادة إنتاج أهم الدحاصيل الاستراتيجية في السنوات الأخبرة إلا أن هذه الزيادة لا تتناسب مع الإحتياجات

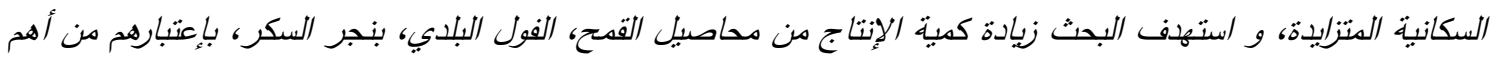

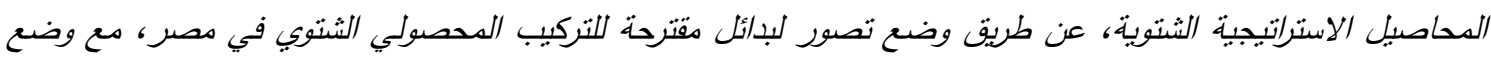
آلية تسدح بتحفيز المزراعين على زيادة الرقعة المنزرعة من تلك الدحاصيل على حساب محصول البرسيم في الدورة الزراعية،

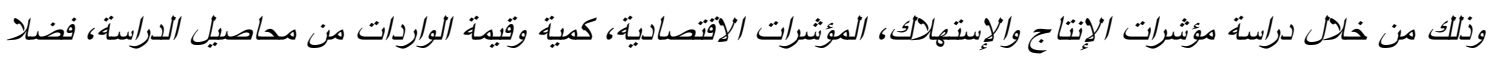

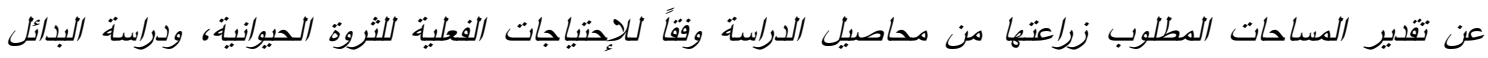
الدقترحة للتركبي الدحصولي الثتوي وآلية تتقبذها عام 2015. وقد توصل البحث إلى مجموعة من النتائج أهمها مايلى: 1- تزايد الدساحة الدنزرعة بدحاصيل القدح، الفول البلدي، بنجر السكر بدعدل ندو سنوي معنوي إحصائياً قدر بنحو

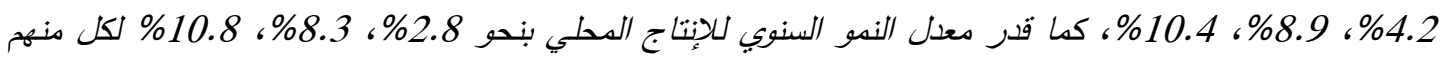

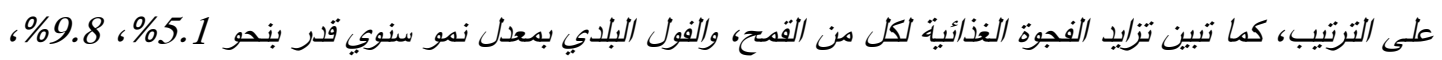

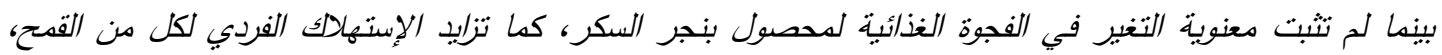

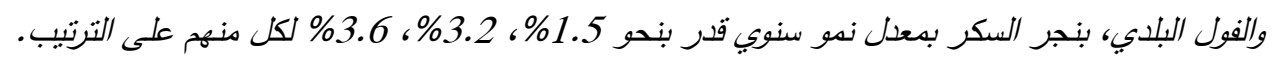

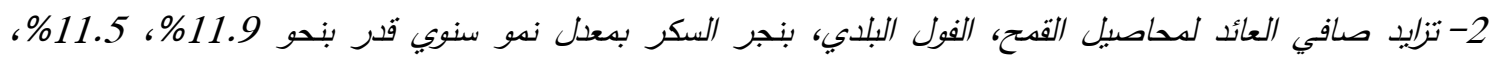

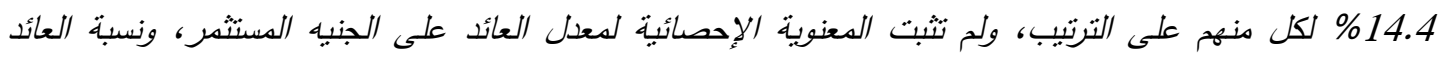

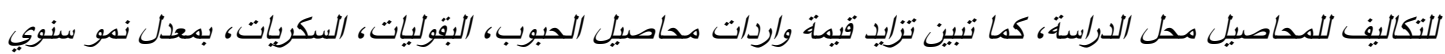
قدر بنحو 11.9\%، 10.1\%، 18\% خال فترة الدراسة، وتزايدت قيمة واردات القدح، الفول البلدي بمعدل ندو سنوي قدر بنحو 12.3\%، 11.3\% على الترتيب، ولم تثبت دعنوية التغبر في قيهة واردات بنجر السكر خلال فترة الدراسة.

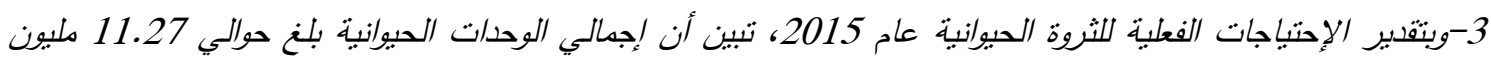

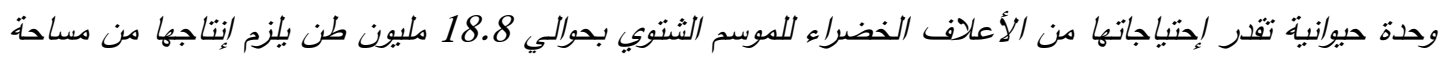
برسيم مقدرها حوالي 625.6 ألف فدان، وبتقلير الدساحات المطلوب زراعتها لتغطية الواردات من كل القدح ، الفول البلاي، بنجر السكر تبين أنها بلغت حوالي 3242.5، 192.1،

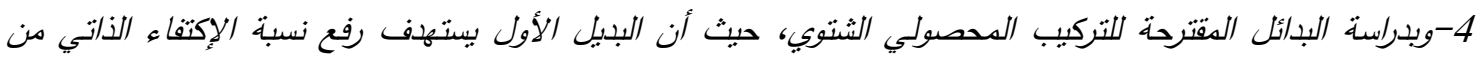

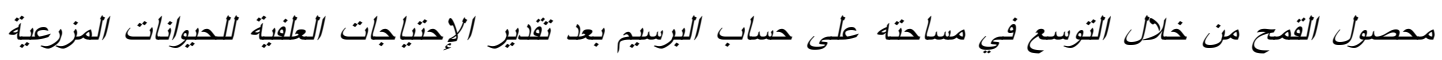
وترتب عليه زيادة نسبة الإكتفاء الذاتي لمحصول القدح لييلغ نحو 65.3\%، ويبتهذف البديل الثاني تحقيق الإكتفاء

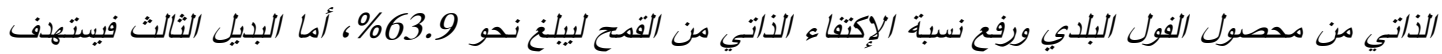


تحقيق الإكتفاء الذاتي من الفول البلدي والسكر ورفع نسبة الإكتفاء الذاتي من القصح على حساب مساحة محصول البرسيم لترتفع نسبة الإكتفاء الذاتي من القدح، وبنجر السكر لنحو 57.22\% 106.94\% على الإنى الترتيب.

واردات الفول البلدي حوالي 278.54 مليون دولار تمثل

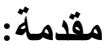
نحو 62.50\% من قيمة واردات البقوليات، أما بنجر السكر فقد قدرت قيمة الواردات منه بحوالي 69.42 مليون دولار تمثل نحو 13.59\% من قيمة واردات السكريات

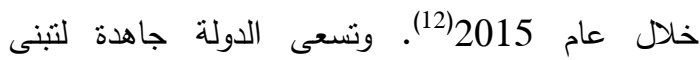
سياسات زراعية من شأنها العمل على تحقيق الإكتفاء الذاتى من نلك المحاصيل والعمل على سد الفجوة الغذائية منها، فقد بلغت الفجوة الغذائية من محاصيل القمح، الفول

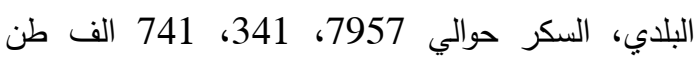

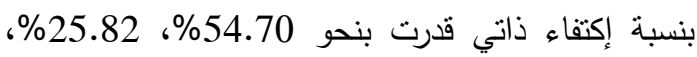
77.12 لكل منهم على الترتيب عام 2015 (9). الأمر الذي استلزم معه دراسة الوضع الحالى للإنتاج و وتقدير

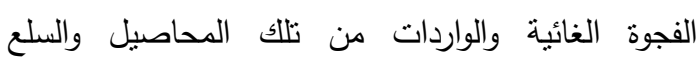
الزراعية لوضع بدائل للتركيب المحصولى الثنتوى تسهر

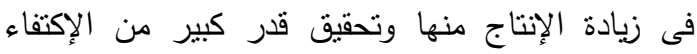

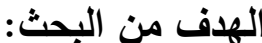

بستهدف البحث زيادة كمية الإنتاج من محاصيل

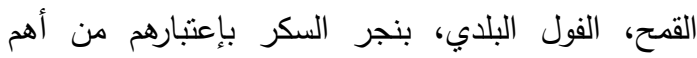

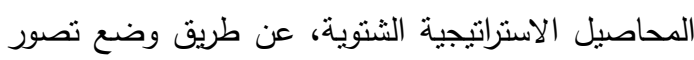

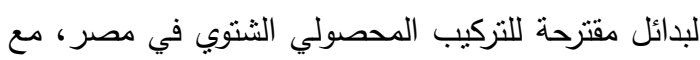
وضع آلية تسمح بتحفيز وتتجيع المزارعين على زيادة لئن الرقعة المنزرعة من تلك المحاصيل على حساب محصول

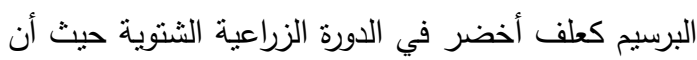
هناك فائض فى البرسيم بعد سد الأحتباجات الحيوانية

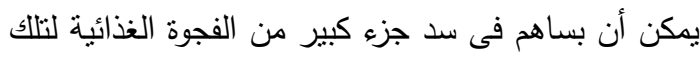
الحاصلات ، بالإضافة إلى تفعيل فكرة التعاقد المسبق

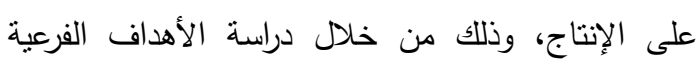
التالية خلال الفترة (2000-2015): أولاً: مؤشرات إنتاج واستهلاك محاصيل الدراسة.

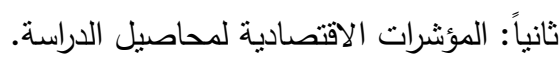

تعتبر قضية الأمن الغذائى من القضايا الأساسية التى مقدي تحظى بإهتهام كبير في مختلف دول العـالم ومـن بينها

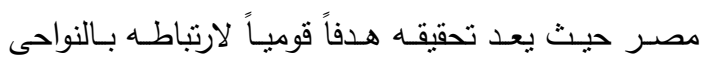

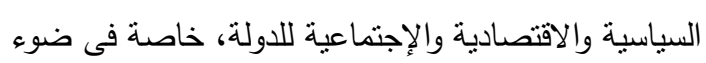

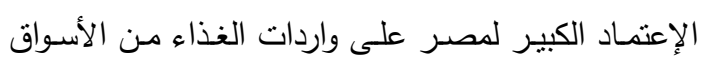

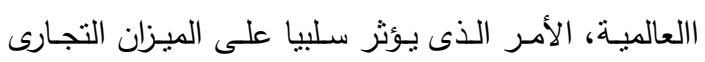

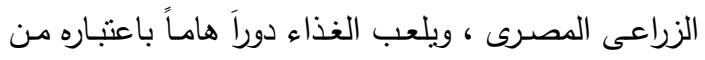

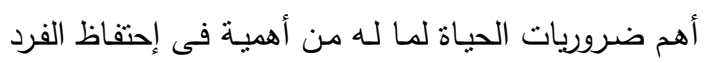

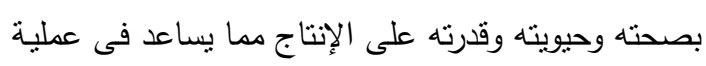

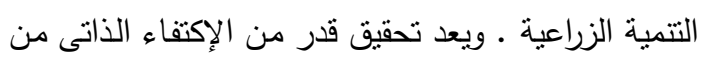

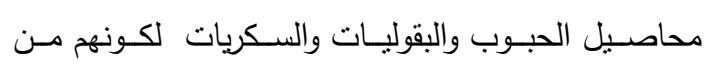
المحاصيل الاستراتيجية الهامة التي تمثل أهمية في الميزان

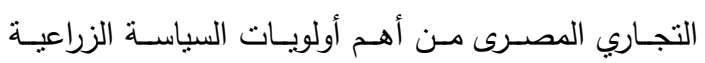

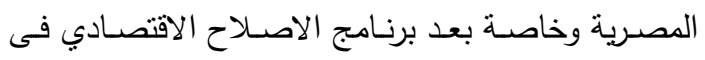

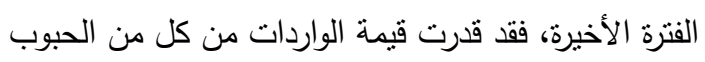

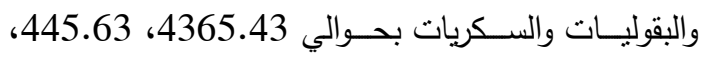

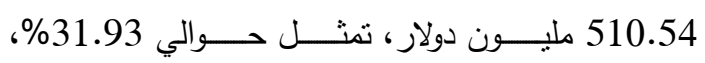

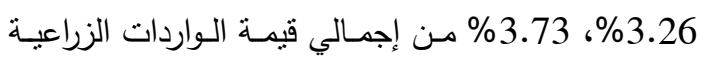

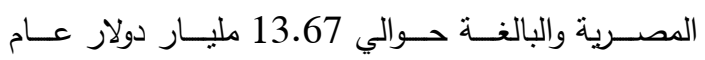

.(12) 2015

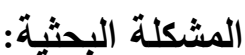

بالرغم من زيادة إنتاج أهم المحاصيل الاستراتيجية في

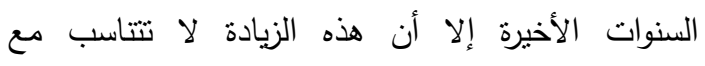

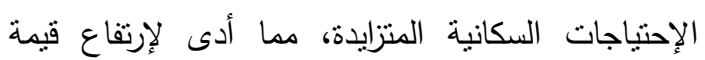

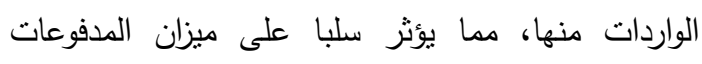
المصرى فى ظل إرتفاع سعر الدولار أمام الجنيه، وتعتبر

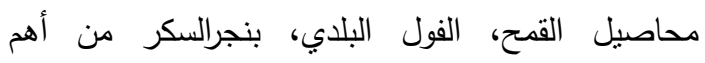
المحاصيل الاستراتيحية والتي ترتفع قيمة وارداتها حيث لهنيل بلغت قيمة واردات القمح حوالي 2.21 مليار دولار تمثل نحو 50.63\% من قيمة واردات الحبوب، وبلغت قيمة 
2001/2000 وحد أقصى بلغ حوالى 9.61 مليون طن عام 2015/2014 بمتوسط سنوى بلغ حوالى ملى

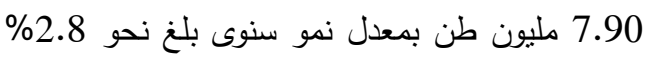

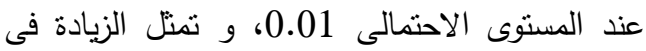
الإنتاج المحلى نحو 205.45 ألف طن سنوياً، كما

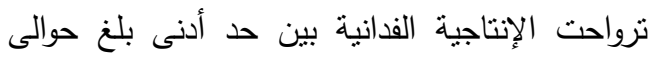

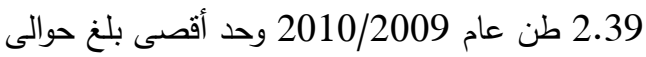
2.80 حوالى 2.71 طن. وبدراسة الإستهلاك من القمح يتبين أنه تراوح بين حد أدني بلغ حوالي 9819 ألف طن عام 2001/2000، وحد أقصي بلغ حوالي 17564 ألف طن عام 2015 بمتوسط سنوي بلغ حوالي 14056.88 ألف طن، فى حين تراوحت الفجوة الغذائية بين حد أدني بلغ حوالي 3564 ألف طن عام 2001/2000، وحد أقصي بلغ حوالي 8507 ألف طن عام 2011/2010 بمنوسط وحام سنوي بلغ حوالي 6154.63 ألف طن، وقدرت الزيادة السنوية بمقدار 506.04 طن بمعدل نمو سنوي قدر بنحو

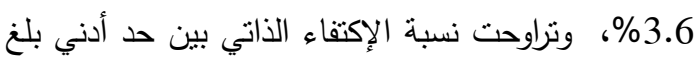

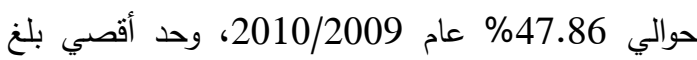

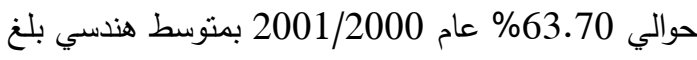
حوالي 56.57\%، وتزاوحت فترة تلبية الإنتاج الدحلى

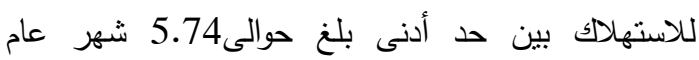
2010/2009 وحد أقصي بلغ حوالي 7.64 شهر عام 2001/2000 بمتوسط سنوي بلغ حوالي 6.81 شهر حولي وأخذت فترة التلبية إتجاهاً عاماً متناقص حيث قلثر قدر مقدار التتاقص السنوي لفترة التلبية حوالي 0.07 شهر بمعدل

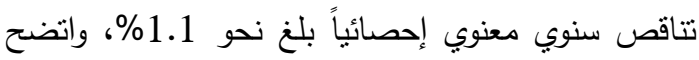
من الدراسة أن متوسط نصيب الاستهلاك الفردي تراوح بين حد أدنى بلغ حوالى 150.28 كجم/سنة عام المبن 2001/2000 وحد أقصى بلغ حوالى 209.9 كجم/سنة عام 2011/2010 بمتوسط عام بلغ 185.27 كجم/سنه وبلغ معدل الزيادة السنوية لمنوسط نصيب الفرد من القمح نحو 2.66 كجم/سنة، بمعدل نمو سنوى معنوي إحصائياً بلغ حوالي 1,5\% خلال فترة الدراسة.
ثالثاً: كمية وقيمة الواردات من محاصيل الدراسة.

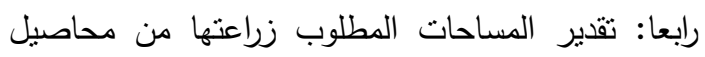
الدراسة وفقاً للإحتياجات الفعلية للثروة الحيوانية في

$$
\text { مصر عام } 2015 .
$$

خامساً: البدائل المقترحة للتركيب المحصولي الثنوي وآلية تنفيذها عام 2015.

$$
\text { الأسلوب البحثي ومصادر البيانات: }
$$

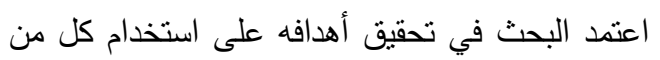

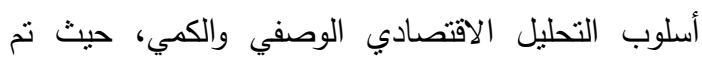

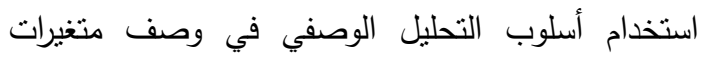
البحث وفي قياس بعض المؤشرات الإنتاجية والاقتصادية المرتبطة بمحاصيل الدراسة، كما تم الاستعانة بأسلوب

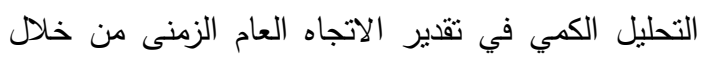

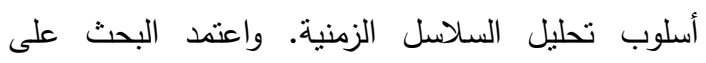
البيانات الثانوية المنشورة من خلال نشرات قطاع الثئون الاقتصادية بوزارة الزراعة واستصلاح الأراضي منل نشرة

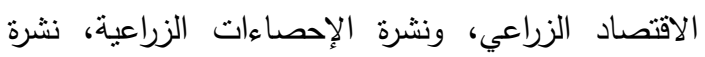

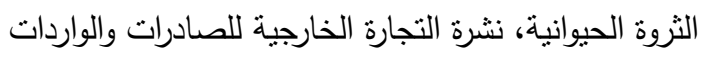

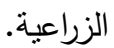

\section{النتائج البحثية:}

أولاً: مؤثرات إنتاج واستهلاك محاصيل الدراسة:

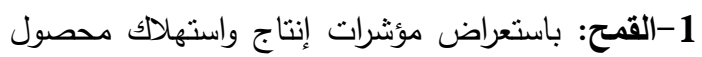

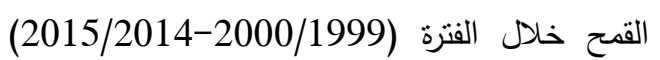
والموضحة بجدول رقم (1) والتحليل الاحصائي لها والواردة بجدول رقم (2) تنين أن المساحة المنزرعة تراوحت بين حد أدنى بلغ حوالى 2.31 مليون فدان عام 2001/2000 وحد أقصى بلغ حوالى 3.47 مليون فدان عام 2015/2014 بمنوسط سنوى بلغ حرالغ حوالى 2.91 مليون فدان بمعدل نمو سنوى معنوى

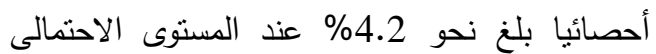

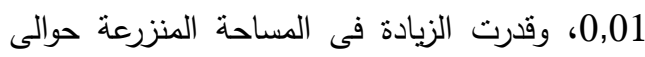
122.2 ألف فدان سنوياً، كما نراوح الإنتاج المحلي لئري بين حد أدنى بلغ حوالى 6.26 مليون طن عام الإن 
جلول رقم (1): تطور الإتتاج والاستهلاك والفجوة الغذائية لمحصول القمح فى مصر خلال الفترة (2000/1999$(2015 / 2014$

\begin{tabular}{|c|c|c|c|c|c|c|c|c|}
\hline الاستهلاك & فلاسنترة تغطية & الإكتفاء & $\begin{array}{c}\text { (الفذائية } \\
\text { (الفنوة }\end{array}$ & (ألف طن) & (طن/فدان) & 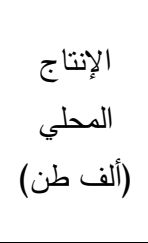 & (مليون & السنوات \\
\hline 173.72 & 7.09 & 59.06 & 4550 & 11114 & 2.67 & 6564 & 2.46 & $2000 / 1999$ \\
\hline 150.28 & 7.64 & 63.70 & 3564 & 9819 & 2.67 & 6255 & 2.31 & $2001 / 2000$ \\
\hline 171.02 & 6.84 & 56.99 & 5000 & 11625 & 2.70 & 6625 & 2.45 & $2002 / 2001$ \\
\hline 160.22 & 7.51 & 62.55 & 4096 & 10936 & 2.71 & 6840 & 2.53 & $2003 / 2002$ \\
\hline 169.54 & 7.33 & 61.06 & 4577 & 11754 & 2.76 & 7177 & 2.61 & $2004 / 2003$ \\
\hline 188.95 & 7.32 & 60.97 & 5212 & 13353 & 2.73 & 8141 & 2.99 & $2005 / 2004$ \\
\hline 197.99 & 6.96 & 58.03 & 5983 & 14257 & 2.70 & 8274 & 3.06 & $2006 / 2005$ \\
\hline 186.99 & 6.43 & 53.57 & 6395 & 13773 & 2.72 & 7378 & 2.72 & $2007 / 2006$ \\
\hline 191.09 & 6.66 & 55.49 & 6398 & 14375 & 2.73 & 7977 & 2.92 & $2008 / 2007$ \\
\hline 189.94 & 7.01 & 58.41 & 6069 & 14592 & 2.71 & 8523 & 3.15 & $2009 / 2008$ \\
\hline 190.25 & 5.74 & 47.86 & 7809 & 14978 & 2.39 & 7169 & 3.00 & $2010 / 2009$ \\
\hline 209.90 & 5.95 & 49.60 & 8507 & 16878 & 2.75 & 8371 & 3.05 & $2011 / 2010$ \\
\hline 189.67 & 6.74 & 56.17 & 6862 & 15657 & 2.78 & 8795 & 3.16 & $2012 / 2011$ \\
\hline 203.36 & 6.60 & 54.97 & 7750 & 17210 & 2.80 & 9460 & 3.38 & $2013 / 2012$ \\
\hline 196.11 & 6.54 & 54.51 & 7745 & 17025 & 2.74 & 9280 & 3.39 & $2014 / 2013$ \\
\hline 195.32 & 6.56 & 54.70 & 7957 & 17564 & 2.77 & 9607 & 3.47 & $2015 / 2014$ \\
\hline 185.27 & 6.81 & 56.57 & 6154.63 & 14056.88 & 2.71 & 7902.25 & 2.91 & المتوسط \\
\hline
\end{tabular}

- - مزارة الزراعة ،قطاع الثئون الاقتصادية، نثرة الميزان الغذائي ،الادارة المركزية للاقتصاد الزراعى، أعداد متفرقة - - مزارة الزراعة ،قطاع الثئون الاقتصادية، نثرة الاحصاءات الزراعية ،الادارة المركزية للاقتصاد الزراعى، أعداد متفرقة. 
Suggested alternatives for winter crop rotation to fill the gap of the

جدول رقم (2) : معادلات الاتجاه الزمنى العام للمؤشرات الإتتاجية والاستهلاكية لمحاصيل القمح والفول البلدي وينجر السكر خلال الفترة (2015/2014-2000/1999)

\begin{tabular}{|c|c|c|c|c|c|}
\hline معدل النمو \% & ف & 2 & المعادلة & الوحدة & البيان \\
\hline 4.2 & " 24.93 & 0.64 & 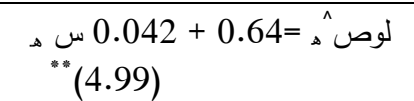 & المنزاحة & \multirow{6}{*}{ القمح } \\
\hline 2.8 & " 57.23 & 0,80 & لوص ه =0.028 + 1.82 س هـ & الإنتاج المحلي & \\
\hline 3.6 & "* 153.2 & 0.92 & لوص هـ =0,036+9,22 س هـ & الاستهلاك & \\
\hline 5.1 & " 67.38 & 0.83 & 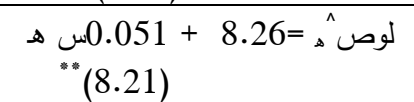 & الفجوة الغذائية & \\
\hline $1.1-$ & " "9.8 & 0.41 & 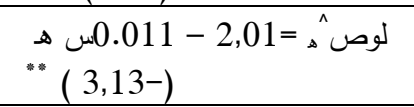 & فترة التلبية & \\
\hline 1.5 & " 22.4 & 0.62 & لوص هـ =5,09+ & الاستهلاك & \\
\hline $8.9-$ & "* 116.54 & 0.89 & 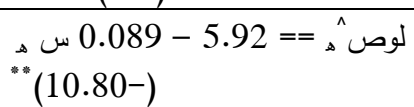 & المنزاحة & \multirow{6}{*}{ الفول البلدي } \\
\hline $8.3^{-}$ & " 112.40 & 0,88 & لوص هـ =6.2- لو & الإنتاج المحلي & \\
\hline 9.8 & 5.21 & 0.27 & 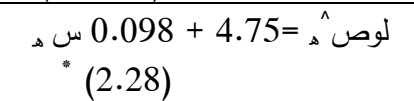 & الفجوة الغذائية & \\
\hline $7.2-$ & " 46.99 & 0.77 & 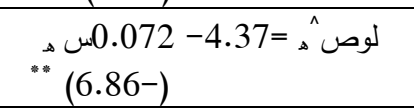 & نسبة الإكتفاء & \\
\hline $7.2-$ & " 47.05 & 0.77 & لوصه =0 - $0.072-25$ س هـ & فترة التلبية & \\
\hline $3.2-$ & 4.6 & 0.25 & 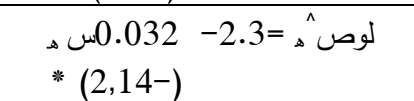 & الاستهلاك & \\
\hline 10.4 & " 282.76 & 0.95 & 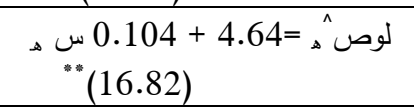 & المنزرة المة & \multirow{7}{*}{ بنجر السكر } \\
\hline 10.8 & " 245.83 & 0,95 & لوص هـ =0.74 +0.108 س هـ & الإنتاج المحلي & \\
\hline 0.3 & 4.27 & 0.23 & 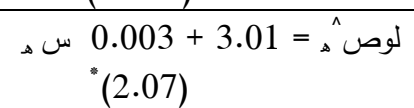 & الإنتاجية & \\
\hline 4 & "* 103.3 & 0.88 & 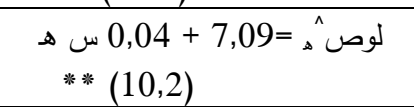 & إنتاج السكر & \\
\hline 5.7 & " 10.9 & 0.88 & $\begin{array}{l}\text { لوصهٌ = 7,2 + 0,57 س هـ } \\
\text { * (10,1) }\end{array}$ & الستهلاك & \\
\hline $1.8^{-}$ & "5.1 & 0.32 & 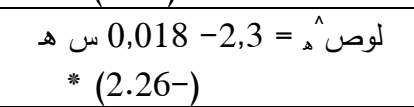 & فترة التلبية & \\
\hline 3.6 & " 37.6 & 0.73 & 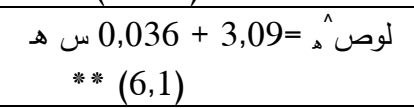 & الاستهلاك & \\
\hline
\end{tabular}

المصدر: حسبت من جداول أرقام (1)، (3)، (4). 
المحلى للإستهلاك بين حد أدنى بلغ حوالى3.10 شهر

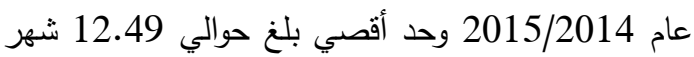
عام 2000/1999 بمتوسط سنوي بلغ حوالي 5.55

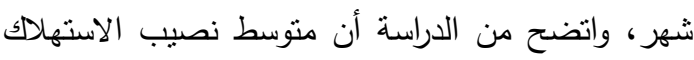
الفردى تراوح بين حد أدنى بلغ حوالى 4,45 كجم/سنة عام 2012/2011 وحد أقصى بلغ حوالى 11,31 كجم/سنة عام 2008/2007 بمتوسط عام بلغ 7,93 كجم/سنه خلا فتزة الدراسة ـ وبتقدير معادلات الاتجاه الزمني لكل

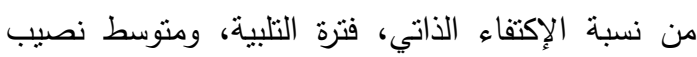
الفرد من الفول البلدي والواردة بجدول رقم (2) تبين أن هناك اتجاه عام متناقص بمعدل تتاقص سنوى معنوي

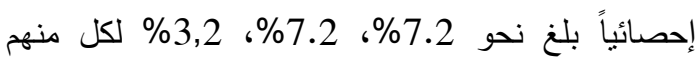
على الترتيب وبلغ مقدار التناقص السنوي لنسبة الإكثفاء الذاتي حوالي 3.1\% ولفترة التلبية حوالي 0.44 شهر في حين بلغ مقدار التتاقص السنوي للاستهلاك الفردي حوالي 0.22 كجم/سنة، وتزايدت الفجوة الغذائية بحوالي 31.91

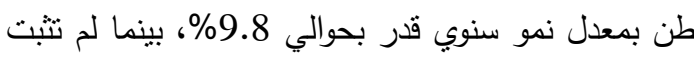
معنوية التغير في الإستهلاك المحلي من الفول البلدي

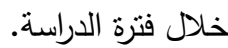

كما يوضح جدول (4) تطور الإنتاج والاستهلاك وكذا الفجوة الغذائية لمحصول بنجر السكر في مصر خلال فترة

3- بنجر السكر: تبين من جدول رقم (5) أن السساحة

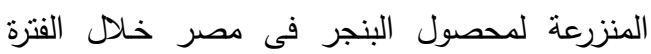

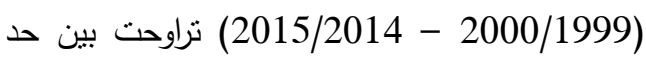

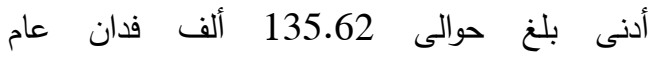
2000/1999 وحد أقصى بلغ حوالى 554.94 ألف فدان عام 2015/2014 بمنوسط عام بلغ حوالى

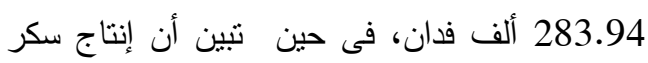

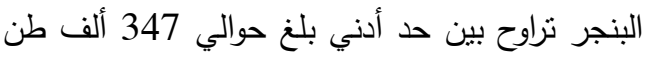
عام 2003/2002، وحد أقصي بلغ حوالي 1348 ألف طن عام 2015/2014 بمتوسط سنوي بلغ بلغ حولي حوالي 701.75 ألف طن، وترواح إنتاج سكر البنجر بين حد أدني بلغ حوالي 1285 ألف طن عام
2- الفول البلاي: باستعراض بيانات الجدول رقم (3) تبين

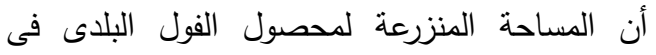
مصر خلال الفترة (2000/1999 - 2015/2014) تراوحت بين حد أدنى بلغ حوالى 81.93 ألف فدان عام 2015/2014 وحد أقصى بلغ حوالى 333.69 ألف فدان عام 2001/2000 بمتوسط عام بلغ حوالى بلى حرالى 199.36 ألف فدان، وتراوح الإنتاج بين حد أدنى بلغ حوالى 118.74 ألف طن عام 2015/2014 وحد وند

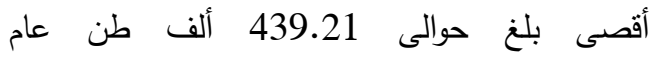
2007/2006 بمتوسط عام بلغ حوالى 270.65 ألف طالف طن، كما نزاوحت الإنتاجية الفدانية بين حد أدنى بلغ بلغ بلغ

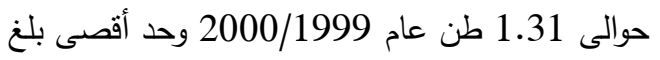
حوالى 1.49 طن عام 1.31 طن عام 2008/2007 بمتوسط عام بلغ حوالى 1.38 طن، وتبين من تقدير معادلات

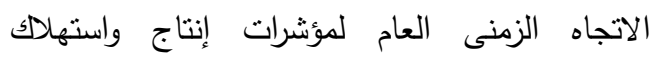
محصول الفول البلدى فى مصر جدول رقم (2) تبين أن هناك اتجاه عام منتاقص لكل من الدساحة

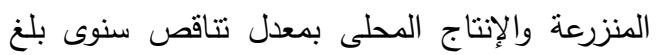

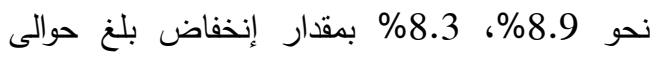
17.74 ألف فدان، 22.46 ألف طن سنوياً لكل منهما على الترتيب عند المستوى الاحتمالى 0.01، ولم تثبت معنوية الإنتاجية الفدانية خلال فنزة الدراسة. وبدراسة الإستهلاك من الفول البلاي تبين أنه تراوح

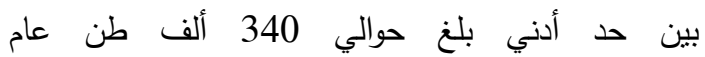
2000/1999، وحد أقصي بلغ حوالي 851 ألف طن طن عام 2008/2007 بمتوسط سنوي بلغ حوالي 588.93

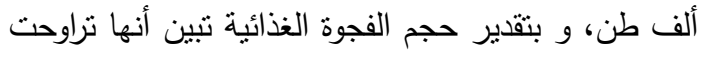

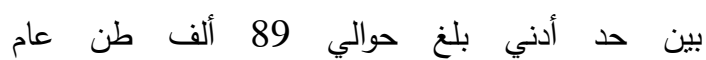
2001/2000، وحد أقصي بلغ حوالي 607 ألف طن طن عام 2008/2007 بمنوسط سنوي بلغ حوالي ألف طن، وتراوحت نسبة الإكتفاء الذاتي بين حد أدني بلغ نحو 25.82 \% عام 2015، وحد أقصي بلغ نحو بلن النية

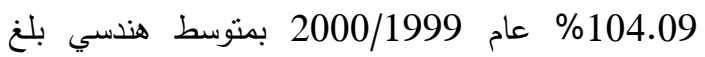
حوالي 42.75\%، فى حين تراوحت فنرة تلبية الإنتاج 
السكر أن هناك اتجاه عام متزايد لكل من المساحة المنزرعة، الإنتاج المحلى، والإنتاجية الفدانية بمعدل

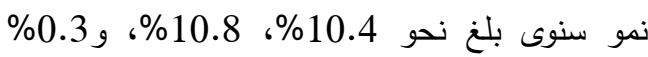
لكل منهم على التزتيب عند المستوى الاحتمالى 0,01 بمقدار زيادة سنوية قدر بحوالي 29.48 ألف فدان،

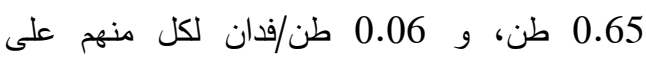
التزتيب.

المصدر: - - الم

- - مزارة الزراعة ،قطاع الشئون الاقتصادية، نشرة الميزان الغذائي ،الادارة المركزية للاقتصاد الزراعى، أعداد متفرقة.

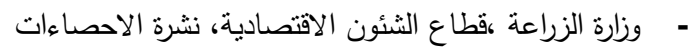
الزراعبة ،الادارة المركزية للاقتصاد الزراعى، أعداد متفرقة.

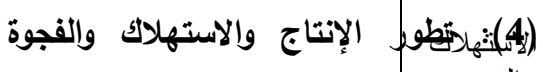

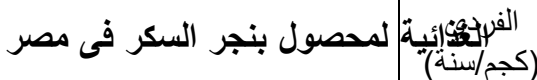
خلال

(2015/20\$\$1
2003/2002، وحد أقصي بلغ حوالي 2498 ألف طن عام 2015/2014 بمتوسط سنوي بلغ حوالي 1721.06 ألف طن، وتراوحت الإنتاجية الفدانية بين

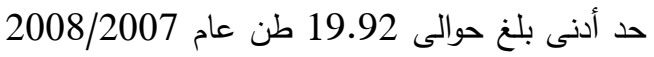

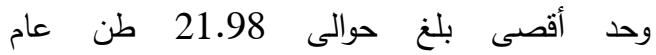
2007/2006 بمتوسط عام بلغ حوالى 20.88 طن، وتبين من تقدير معادلات الاتجاه الزمنى العام لأهم

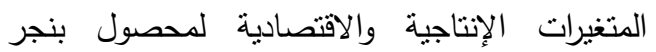

جدول رقم (3): تطور الإتتاج والاستهلاك والفجوة الغذائية لمحصول الفول البلاي فى مصر خلال الفترة (2000/1999-

(2015/2014 
Ghada S. Hassan and Safaa M. El-Wakeel

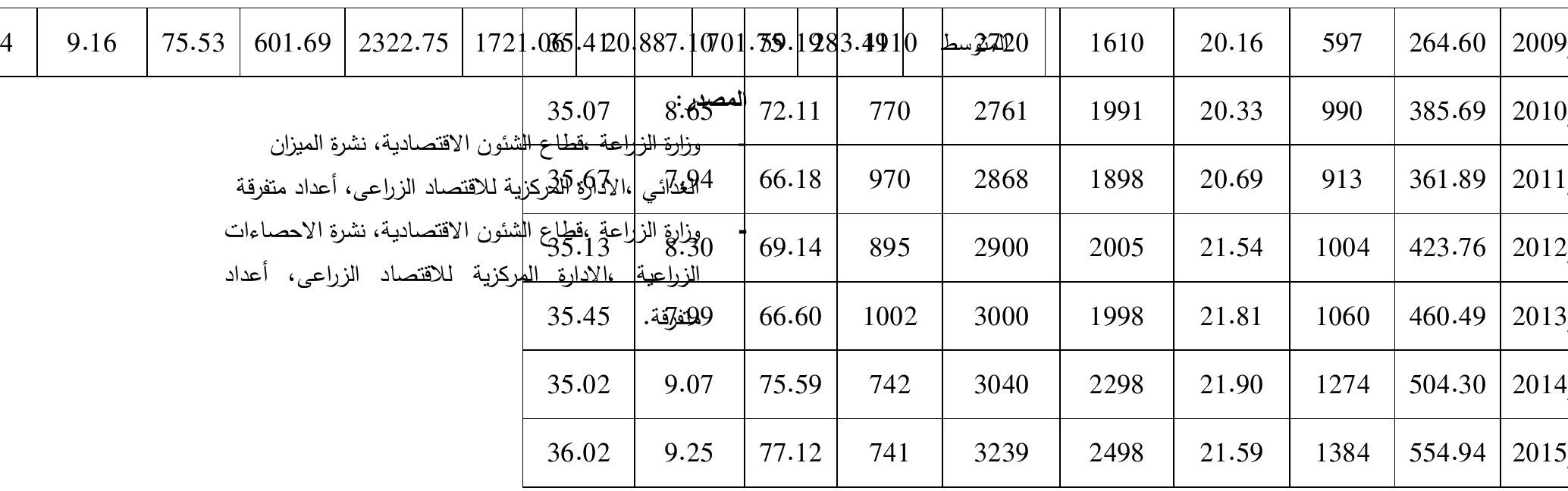


Suggested alternatives for winter crop rotation to fill the gap of the

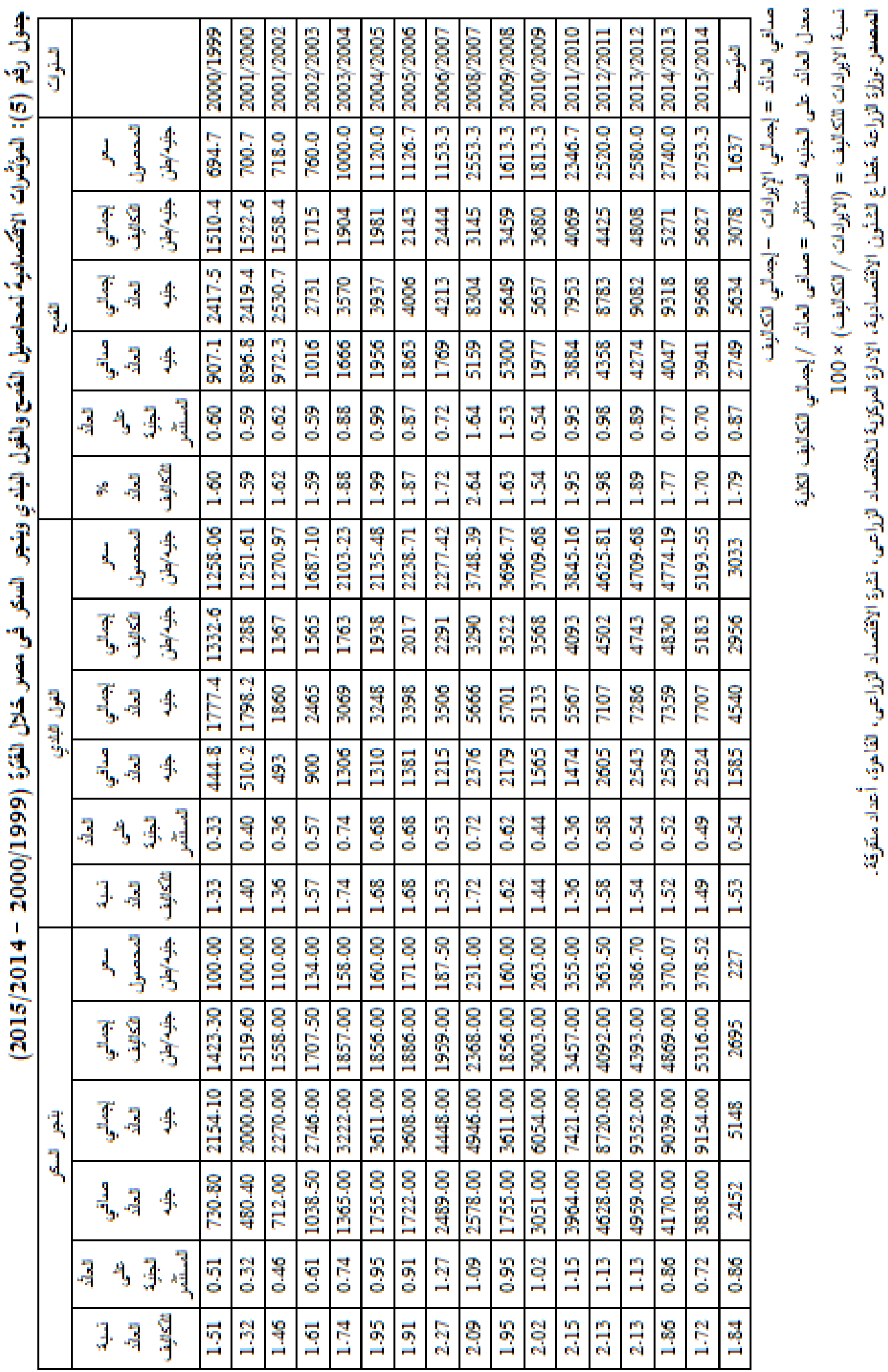


جنيه/فدان عام 2001/2000 وحد أقصى بلغ حوالى 5300 جنيه/فدان عام 2009/2008 بمتوسط عام بلغ حوالى 2749.14 جنيه/فدان، بمعدل نمو سنوى بلغ نحو 9.8\% عند المستوى الاحتمالى 0,01، بمقدار زيادة بلغ حوالى1327.15 جنيد/فدان. وبتقدير العائد على الجنيه المستثمر تبين أنه نراوح بين حد أدنى بلغ

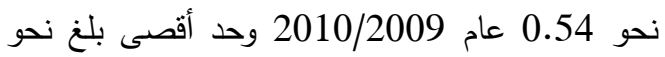
1.64 عام 2008/2007 بمتوسط عام بلغ نحو 0.87 خلاد فترة الدراسة.

2-الفول البلدي: تبين من جدول رقم (5) أن السعر

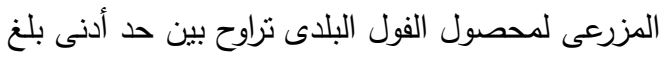
حوالى 1.25 ألف جنيد/طن عام 2001/2000 وحد أقصى بلغ حوالى 5.19 ألف جنيد/طن عام 2015/2014 بمتوسط عام بلغ حوالى 3.33 ألف كالف جنيه/طن، كما تراوح إجمالى التكاليف الفدانية بين حد أدنى بلغ حوالى 1288 جنيه/فدان عام وحد أقصى بلغ حوالى 5183 جنيه/فدان عام عام عان 2015/2014 بمنوسط عام بلغ حوالى 2955.78 جنيه/فدان، كما تراوح صافى العائد الفدانى بين حد

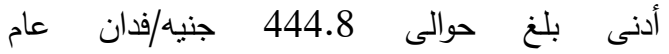
2000/1999 وحد أقصى بلغ حوالى 2605 جنيه/فدان عام 2012/2011 بمتوسط عام بلغ حوالى ولى 1584.69 جنيه/فدان خلال فترة الدراسة. وبتقدير معدل العائد على الجنيه المستثمر تبين أنه تراوح بين

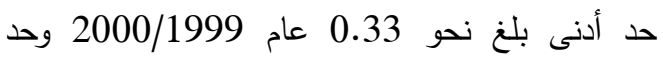

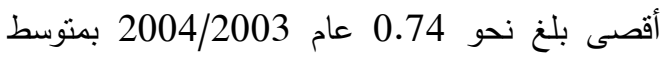
عام بلغ نحو 0.54 خلال فنرة الدراسة. بتقدير

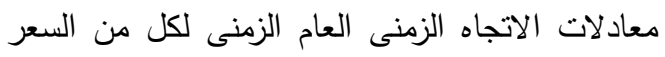

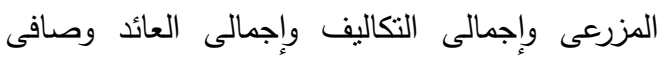
العائد الفدانى والواردة بجدول رقم (6) تبين أن هناك

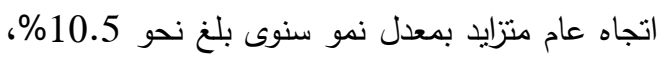
11.3\%، 11.3\%، 11.5\% لكل منهم على الترتيب عند المستوى الاحتمالى 0,01، وتمتل الزيادة حوالى لثى 318.45 جنيد/طن، 334 جنيه/فدان، 513.07 جنيه/فدان، 182.24 جنيه/فدان لكل منهم سنوياً على

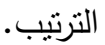

وتبين من تقدير معادلات الاتجاه الزمنى العام أن كل من استهلاك السكر، و متوسط نصيب الفرد من السكر يتزايد زيادة معنوية إحصائياً بمعدل نمو سنوى بلغ حوالى الى

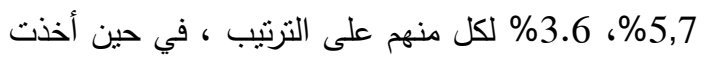

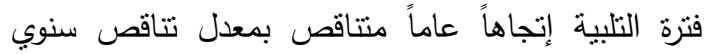

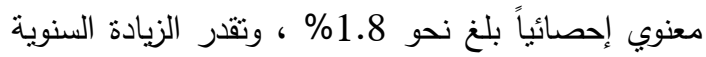

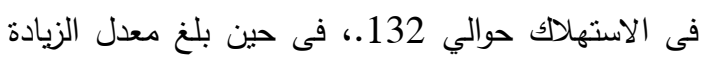
السنوية لمتوسط نصيب الفرد من السكر نحو 1,04 كجم/سنة، وقدر مقدار التتاقص السنوي لفترة التلبية حوالي 0.16 شهر خلال فترة الدراسة كما هوموضح بالجدول رقم

ثانياً: المؤشرات الاقتصادية لمحاصيل الدراسة. 1-القمح: باستعراض المؤشرات الاقتصادية لمحصول

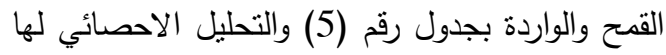
بجدول رقم (6) تبين أن السعر المزرعي نراوح بين حد ولئ

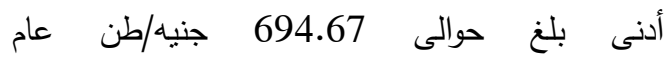
2000/1999 وحد أقصى بلغ حوالى 2753.33 جنيه/طن عام 2015/2014 بمنوسط عام بلغ حوالى وحلى

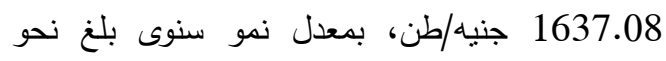
10.8\% عند المستوى الاحتمالى 0,010 بـ، وتمثل الزيادة

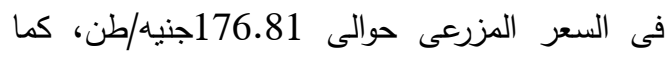
تراوحت إجمالى التكاليف الفدانية بين حد أدنى بلغ الفي حوالى 1510.4 جنيد/فدان عام 2000/1999 وحد الهد أقصى بلغ حوالى 5627 جنيه/فدان 3078.93 2015/2014 بمتوسط عام بلغ حوالى

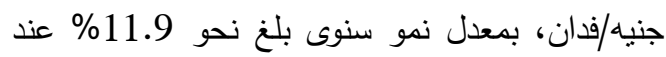
المستوى الاحتمالى 0,01، بمقدار زيادة بلغ حوالى لئى 301.73 جنيه/فدان، وتراوح إجمالى العائد الفاني بين باني

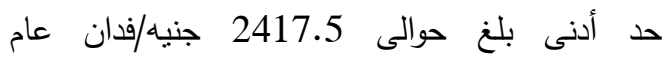
2000/1999 وحد أقصى بلغ حوالى حلى 9568

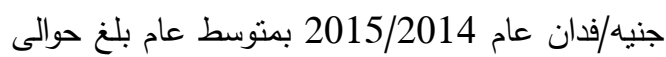

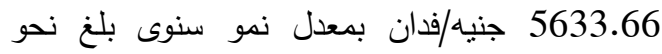

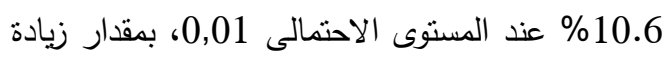
بلغ حوالى 597.17 جنيه/فدان. في حين تراوح صافى الأئى العائد الفدانى بين حد أدنى بلغ حوالى 896.8 
جلول رقم (6): التحليل الاحصائي للمؤشرات الاقتصادية لمحاصيل القمح والفول البلاي وينجر السكر خلال الفترة (2015/2014-2000/1999)

\begin{tabular}{|c|c|c|c|c|c|}
\hline النمو \% معدل & ف & ر & المعادلة & البيان & المحصول \\
\hline 10.8 & " 140.15 & 0.91 & 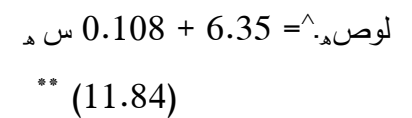 & 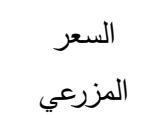 & \multirow{4}{*}{ القمح } \\
\hline 9.8 & " 716.9 & 0.98 & 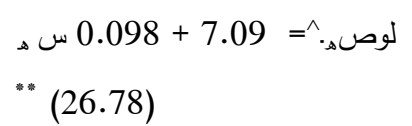 & إلتكاليف & \\
\hline 10.6 & " 165.46 & 0.92 & لوصه.^= 7.62 + 0.106 س هـ & إجمالي العائد & \\
\hline 11.9 & $" 42.31$ & 0.75 & 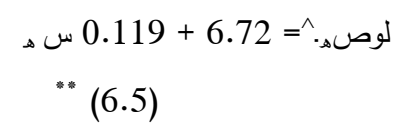 & صافي العائد & \\
\hline 10.5 & " 251.45 & 0.95 & 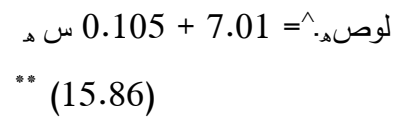 & المزرعي - المعر & \multirow{4}{*}{ الفول البلدي } \\
\hline 11.3 & " 426.16 & 0.97 & 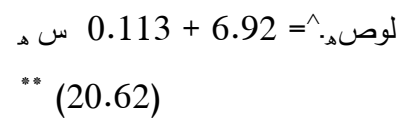 & إلتكاليف & \\
\hline 11.3 & "*178.89 & 0.94 & 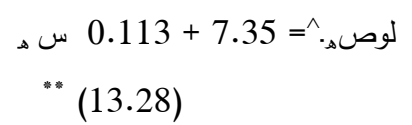 & إجمالي العائد & \\
\hline 11.5 & "*39.1 & 0.77 & لوصه.^= 6.28 + 0.115 س هـ & صافي العائد & \\
\hline 10 & " 177.87 & 0.93 & 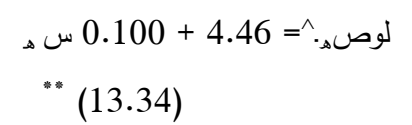 & المزرعي - المعر & \multirow{4}{*}{ بنجر السكر } \\
\hline 9 & "*11.27 & 0.90 & لوصه.^= $0.090+7.04$ س هـ & 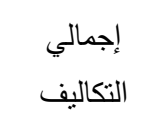 & \\
\hline 11.1 & " 233.06 & 0.94 & 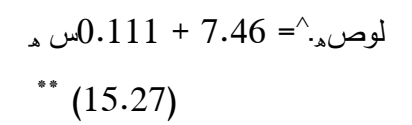 & إجمالي العائد & \\
\hline 14.4 & "107.54 & 0.89 & 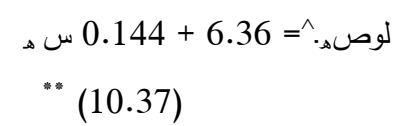 & صافي العائد & \\
\hline
\end{tabular}

المصدر: حسبت من الجدول (5). 
حوالى 22.68 جنيه/طن، 242.55 جنيه/فدان، 571.35 جنيه/فدان، 353.12 جنيه/فدان سنوياً

لكل منهم على الترتيب.جدول رقم (6).

وباستعراض العائد على الجنيه المستثمر على المحاصيل الثنتيه عام 2015 كما هو موضح بالجدول رقم (7) يتضح أن أعلى المحاصيل من حيث العائد على دلى الجنيه المستثر هو محصول البرسيم المستديم حيث جاء

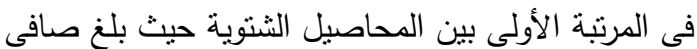
العائد الفدانى حوالى 11924 جنيه، كما بلغ العائد على الأى الجنيه المستثمر حوالى 3.4، يليه البرسيم التحريش حيث بلغ صافى العائد حوالى 5390 جنيه وبلغ العائد على لئى لئل الجنيه المستثمر حوالى 2.3 وجاء بعد ذلك كل من الثعير والكتان حيث بلغ صافى العائد حوالى 3645 جنيه، 3811 جنيه بعائد على الجنيه المستثمر حوالى 0.96، و 0.93، ثم جاء بعد ذلك محصول بنجر السكر بلثر والقمح بصافى عائد بلغ حوالى جنيه بعائد على الجنيه المستثر بلغ حوالى 0.72، 0.70 لكل منهما على الترنيب، وبينما جاء محصول العدس والفول البلدى بصافى عائد بلغ حوالى لئى 2746

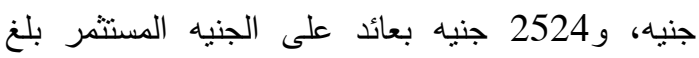
حوالى 0.62، 0.49 لكل منهما على الترتيب.
3-بنجر السكر: تراوحت إجمالى التكاليف الفدانية لمحصول بنجر السكر بين حد أدنى بلغ حوالى 1.42

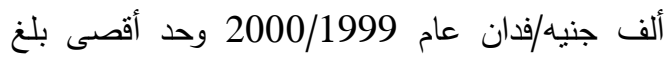
حوالى 5.32 ألف جنيد/فدان عام 2015/2014 بمتوسط عام بلغ حوالى 2.69 ألف جنيد/فدان، فى حين تراوح صافى العائد الفدانى بين حد أدنى بلغ حوالى 480.4 ألف جنيه/فدان عام $2001 / 2000$ وحد أقصى بلغ حوالى 4.96 ألف جنيه/فدان عام عام 2013/2012 بمنوسط عام بلغ حوالى 2.45 ألف جنيه/فدان. وبتقدير معدل العائد على الجنيه المستثر بانى تبين أنه نراوح بين حد أدنى بلغ نحو 0.32 عام 2001/2000 وحد أقصى بلغ نحو 1.27 عام بلغ ندام 2007/2006 بمتوسط عام بلغ نحو 0.86 خلال فترة

الدراسة كما هو موضح بجدول رقم (5). بتقدير معادلات الاتجاه الزمنى العام لأهم المؤشرات الاقتصادية لمحصول بنجر السكر تنين

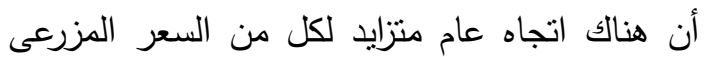
وإجمالى التكاليف وإجمالى العائد وصافى العائد الفدانى بمعدل نمو سنوى بلغ نحو 10\%، 9 \% 11.1\%، 14.4\% لكل منهم على الترتيب عند المستوى الاحتمالى 0.01، بمقدار زيادة سنوية بلغ

جدول رقم (7): العائد على الجنيه المستثمر لأهم الحاصلات الثتوية لعام 2015

\begin{tabular}{|c|c|c|c|c|}
\hline \multirow{2}{*}{ الترتيب } & \multirow{2}{*}{ الجنيه المستثمر } & صافى العائد & المساحة & \multirow{2}{*}{ الدحصول } \\
\hline & & (ألف جنيد/فدان) & (ألف فدان) & \\
\hline السادس & 0.7 & 3941 & 2910 & القمح \\
\hline الثالث & 0.96 & 3645 & 62.19 & الثعبر \\
\hline الثامن & 0.49 & 2524 & 81.93 & الفول \\
\hline السابع & 0.62 & 2746 & 1.46 & العدس \\
\hline الخامس & 0.72 & 3838 & 554.94 & بنجر السكر \\
\hline الرابع & 0.93 & 3811 & 7.45 & الكتان \\
\hline الأول & 3.4 & 11924 & 1298 & برسيم مستنيم \\
\hline الثانى & 2.3 & 5390 & 228.06 & برسيم تحريش \\
\hline
\end{tabular}

المصدر : جمعت وحسبت من نشرة التكاليف وصافى العائد 2015/2014 
ثالثأ: كمية وقيمة الواردات من محاصيل الاراسة:

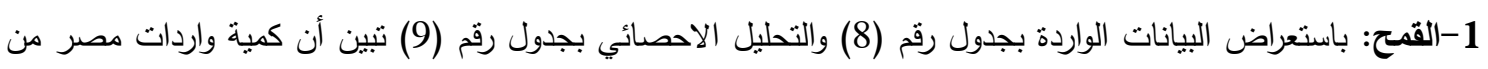
القمح تراوحت بين حد أدنى بلغ حوالي 4057,23 ألف طن عام

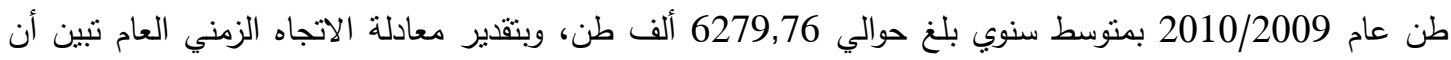

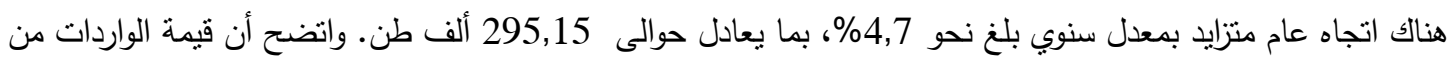

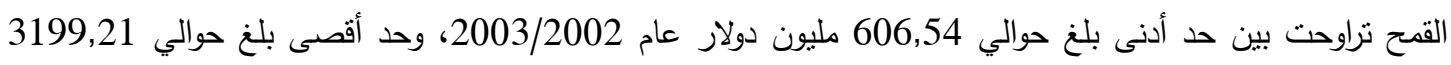
مليون دولار عام 2011/2010 بمنوسط سنوي بلغ حوالي

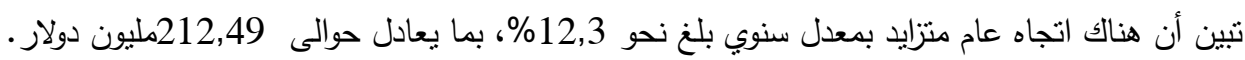
وبدراسة قيمة الواردات المصرية من مجموعة الحبوب تبين أنها تراوحت بين حد أدنى بلغ حوالى 1092,81 مليون دولار

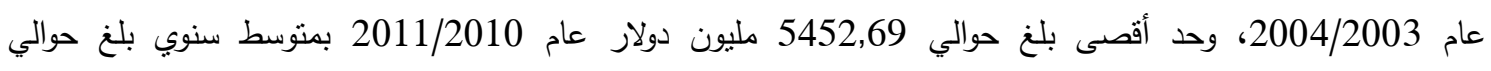

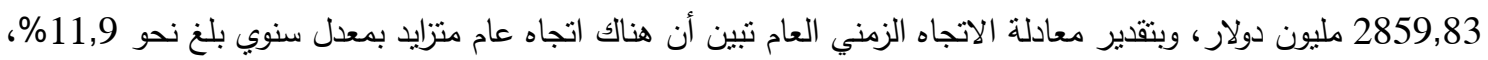

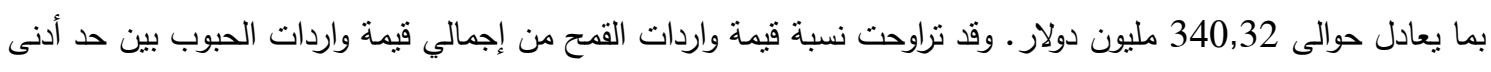

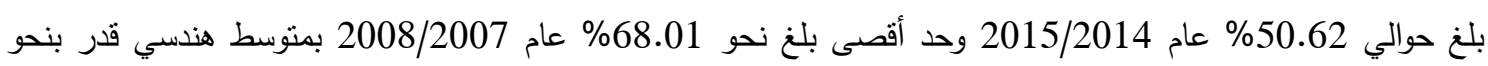
60.41 من إجمالي قيمة واردات الحبوب خلال فنرة الدراسة. ولم تثتبت معنوية التقدير .

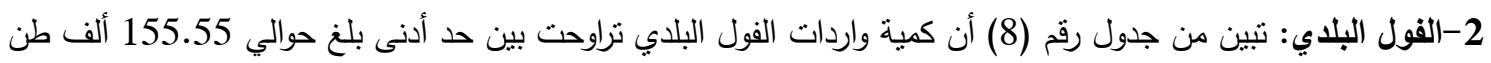

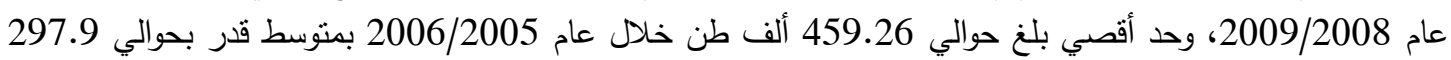
ألف طن، كما ترواحت قيمة الواردات من الفول البلدى بين حد أدنى بلغ حوالي 73.16 مليون دولام الفار عام

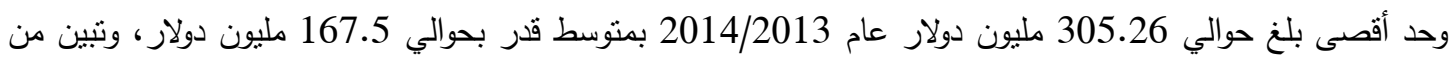

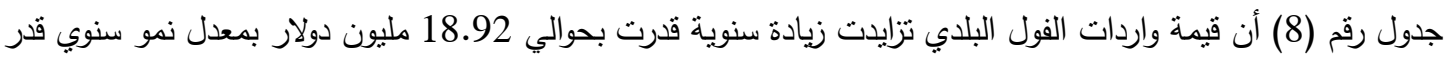

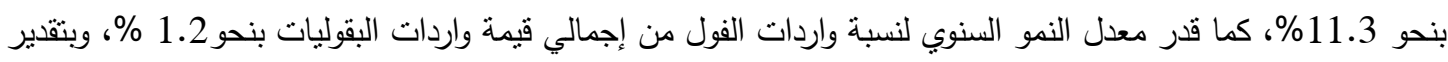

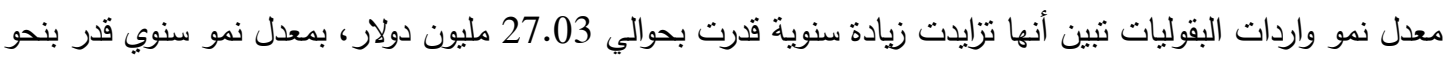

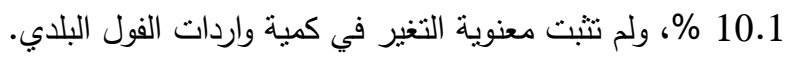

3-بنجر السكر: تبين من جدول رقم (8) وجدول رقم (9) كمبة الواردات من سكر البنجر أن تراوحت بين حد أدنى بلغ

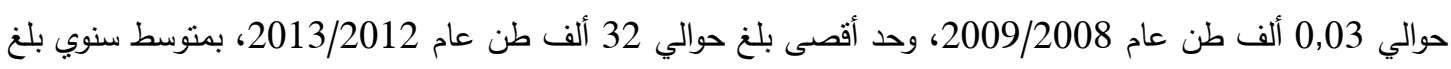

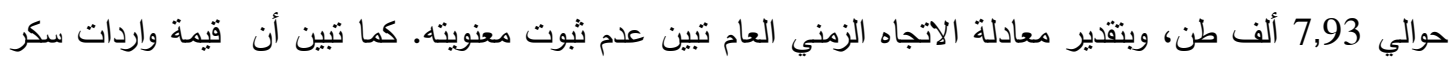

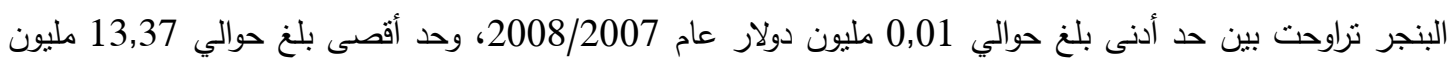

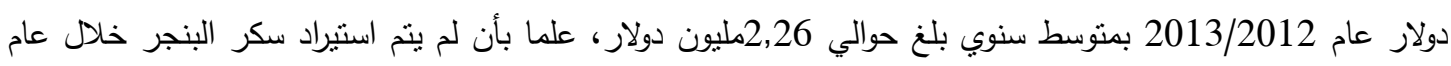

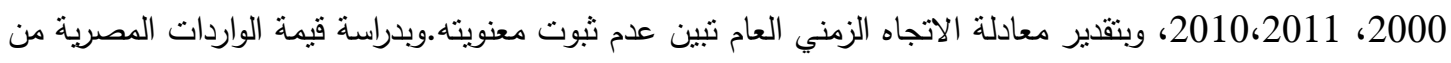

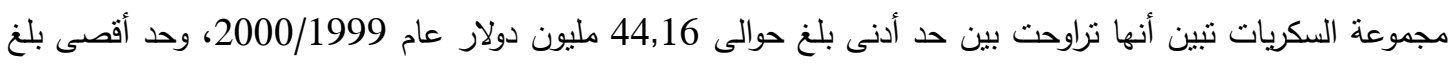

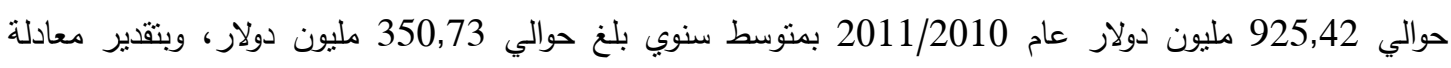

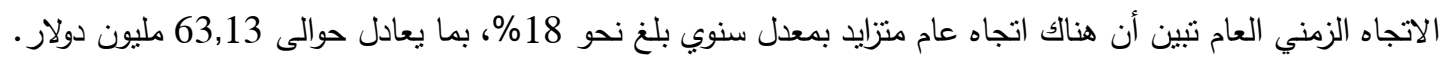


Suggested alternatives for winter crop rotation to fill the gap of the

\begin{tabular}{|c|c|c|c|c|c|c|c|c|c|c|c|c|c|c|c|c|c|c|}
\hline & 3 & $\begin{array}{l}\stackrel{9}{8} \\
\stackrel{8}{8} \\
\text { 울 }\end{array}$ & 을 & 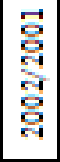 & 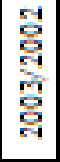 & m: & 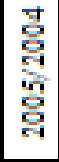 & 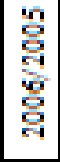 & 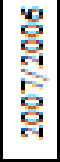 & $\begin{array}{l}\text { 응 } \\
\text { : } \\
\text { 웜 }\end{array}$ & $\begin{array}{l}\text { 을 } \\
\text { 형 } \\
\text { 워 }\end{array}$ & $\begin{array}{l}\text { g. } \\
\text { 웜 } \\
\text { 음 } \\
\text { 워 }\end{array}$ & 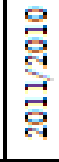 & 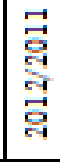 & 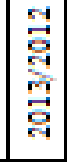 & 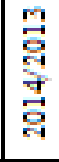 & 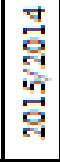 & - \\
\hline \multirow{4}{*}{3} & $\begin{array}{l}3 \\
3 \\
3 \\
3\end{array}$ & $\begin{array}{l}\text { 웅 } \\
\text { 骂 } \\
\text { g }\end{array}$ & 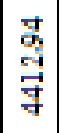 & 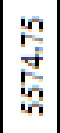 & 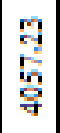 & 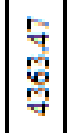 & $\begin{array}{l}0 \\
5 \\
5 \\
5 \\
5\end{array}$ & \begin{tabular}{|l|}
$\overrightarrow{5}$ \\
0 \\
$\mathbf{5}$ \\
$\mathbf{5}$
\end{tabular} & 壱 & $\begin{array}{l}\text { 足 } \\
\text { E⿱ } \\
\text { g }\end{array}$ & $\begin{array}{l}\text { m } \\
\text { \% } \\
\text { Oे }\end{array}$ & 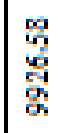 & \begin{tabular}{|l}
$\%$ \\
\%ั \\
\% \\
\%
\end{tabular} & 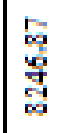 & 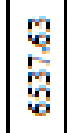 & 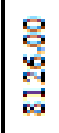 & 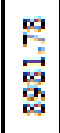 & 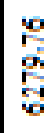 \\
\hline & $\begin{array}{ll}9 & 3 \\
3 & 3 \\
3 & 3\end{array}$ & 発 & $\begin{array}{l}6 \\
6 \\
8\end{array}$ & $\mid \begin{array}{l}5 \\
5 \\
3 \\
0\end{array}$ & 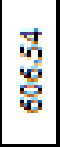 & \begin{tabular}{|l|} 
\\
$\vdots$ \\
$:$ \\
1 \\
1
\end{tabular} & 点 & 㤐 & 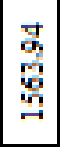 & $\begin{array}{l}\overrightarrow{5} \\
\stackrel{\Xi}{\Xi} \\
\vec{c}\end{array}$ & $\begin{array}{l}2 \\
0 \\
0 \\
0 \\
5 \\
2\end{array}$ & $\begin{array}{l}\overrightarrow{5} \\
\overrightarrow{7} \\
\text { 总 }\end{array}$ & $\begin{array}{l}\vec{z} \\
\text { 学 } \\
\text { m }\end{array}$ & 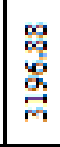 & \begin{tabular}{|c|} 
\\
学 \\
学 \\
\end{tabular} & 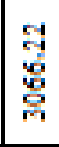 & m & 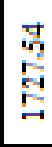 \\
\hline & 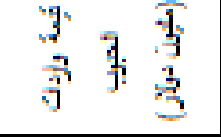 & $\begin{array}{l}\text { ga } \\
\text { जี } \\
\text { a }\end{array}$ & בิ & \begin{tabular}{|c|}
0 \\
$\vdots$ \\
$\vdots$ \\
$\vdots$ \\
$\vdots$ \\
\end{tabular} & 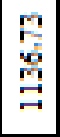 & \begin{tabular}{|l|} 
\\
0 \\
$\vdots$ \\
$\vdots$ \\
0 \\
0
\end{tabular} & 青 & 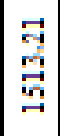 & 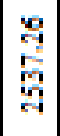 & 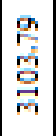 & $\begin{array}{l}\text { 点 } \\
\text { 筞 } \\
\text { व }\end{array}$ & 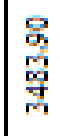 & $\begin{array}{l}\text { \% } \\
\text { ปี } \\
\text { जै }\end{array}$ & 点 & 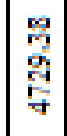 & स् & 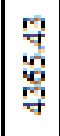 & 哭 \\
\hline & 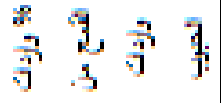 & 守 & 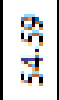 & $\begin{array}{c}2 \\
0 \\
\vdots \\
i\end{array}$ & 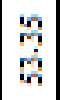 & 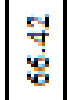 & क⿱ & 常 & : & $\begin{array}{l}\overrightarrow{0} \\
\dot{0} \\
\dot{b}\end{array}$ & 察 & שृ & 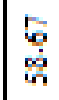 & 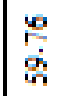 & \begin{tabular}{|c|} 
\\
总 \\
$\dot{8}$
\end{tabular} & $\begin{array}{l}0 \\
\stackrel{0}{0} \\
\dot{8}\end{array}$ & 究 & चे \\
\hline \multirow{4}{*}{$\begin{array}{l}3 \\
3 \\
3 \\
3\end{array}$} & 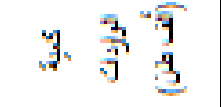 & $\vec{\exists}$ & วี & 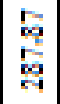 & 它 & 号 & 管 & $\begin{array}{l}\text { ga } \\
\text { g } \\
\text { g }\end{array}$ & 翌 & 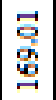 & 总 & 总 & 無 & 学 & 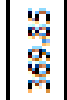 & 衤 & 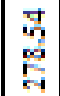 & $\begin{array}{l}9 \\
5 \\
5\end{array}$ \\
\hline & $\begin{array}{ll}9 & 3 \\
3 & 3 \\
3 & 3\end{array}$ & $\begin{array}{l}\stackrel{0}{6} \\
\tilde{n}\end{array}$ & 总 & $\begin{array}{l}2 \\
2 \\
2\end{array}$ & $\begin{array}{l}\text { 壳 } \\
\text { : }\end{array}$ & \begin{tabular}{|c|} 
\\
$\vdots$ \\
$\vdots$ \\
$\vdots$ \\
$\vdots$
\end{tabular} & \begin{tabular}{|l}
$\overrightarrow{0}$ \\
$\vdots$ \\
$\vdots$
\end{tabular} & 总 & 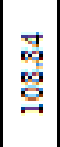 & 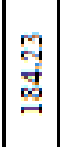 & 営 & 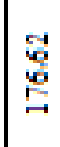 & $\begin{array}{l}5 \\
3 \\
\text { G }\end{array}$ & 号 & $\begin{array}{l}z \\
\text { a } \\
\text { aे }\end{array}$ & 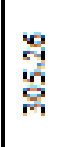 & 望 & 号 \\
\hline & $\begin{array}{ll}3 & \frac{1}{3} \\
3 & 3 \\
3\end{array}$ & 窝 & $\begin{array}{l}\text { m } \\
m \\
m \\
m \\
m\end{array}$ & $\begin{array}{l}\text { 马 } \\
\text { 学 } \\
\end{array}$ & 尽 & 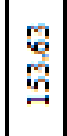 & 吾 & $\begin{array}{l}0 \\
9 \\
02 \\
0 \\
-3\end{array}$ & 武 & 登 & 总 & 总 & 学 & 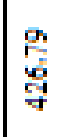 & 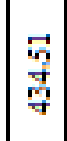 & $\begin{array}{l}5 \\
5 \\
2 \\
y\end{array}$ & 㝵 & 客 \\
\hline & 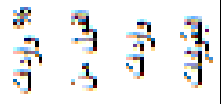 & 号 & 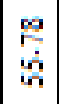 & $\underset{\substack{q \\
\dot{g}}}{\stackrel{m}{q}}$ & $\begin{array}{c}6 \\
6 \\
0\end{array}$ & \begin{tabular}{|l|} 
\\
0 \\
2 \\
8
\end{tabular} & \begin{tabular}{|l|} 
\\
S \\
亏
\end{tabular} & $\begin{array}{l}9 \\
2 \\
\vdots \\
0 \\
6\end{array}$ & \begin{tabular}{l}
0 \\
\hdashline \\
0 \\
\hdashline
\end{tabular} & है & 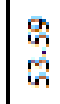 & 穴 & 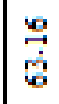 & \begin{tabular}{|l}
5 \\
5 \\
$\dot{0}$ \\
$\dot{6}$
\end{tabular} & \begin{tabular}{|c|}
0 \\
0 \\
$\vdots$ \\
$\vdots$ \\
6
\end{tabular} & 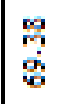 & $\begin{array}{l}\vec{b} \\
\dot{b} \\
\dot{6}\end{array}$ & 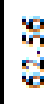 \\
\hline \multirow{4}{*}{ 衫 } & 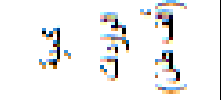 & 1 & 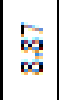 & 等 & \begin{tabular}{|l|} 
: \\
à \\
gे
\end{tabular} & 登 & \begin{tabular}{|l|l}
20 \\
0 \\
05 \\
50
\end{tabular} & 挐 & \begin{tabular}{|l|} 
\\
0 \\
5 \\
$\infty$
\end{tabular} & ్ㅗㅇ & 웅 & 1 & 1 & 今ે & 离 & 웅 & 잉 & $\frac{2}{2}$ \\
\hline & $\begin{array}{ll}3 & \frac{1}{3} \\
3 & 3 \\
3 & 3\end{array}$ & 1 & 焉 & 茎 & 量 & 駡 & 8 & $\stackrel{9}{9}$ & $\overrightarrow{\vec{q}}$ & 홍 & 옹 & 1 & ' & 곻 & \begin{tabular}{|l}
5 \\
2 \\
9 \\
9
\end{tabular} & y & 哭 & 空 \\
\hline & 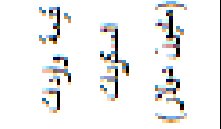 & $\stackrel{9}{\mathcal{Z}}$ & 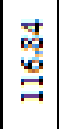 & 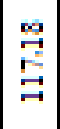 & $\begin{array}{l}\stackrel{9}{2} \\
2 \\
F\end{array}$ & $\begin{array}{l}0 \\
2 \\
6 \\
6\end{array}$ & 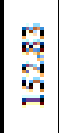 & 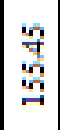 & \begin{tabular}{l}
-1 \\
0 \\
0 \\
0 \\
\hdashline
\end{tabular} & 䰹 & 焉 & $\begin{array}{l}\text { g } \\
\text { g } \\
\text { g }\end{array}$ & 势 & 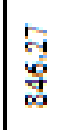 & $\begin{array}{l}\text { zे } \\
\text { 号 } \\
\text { g }\end{array}$ & 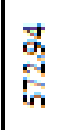 & 总 & 管 \\
\hline & 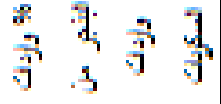 & & : & 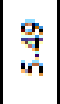 & 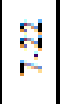 & 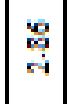 & 号 & 占 & 导 & 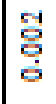 & ؛े & ' & ' & 管 & 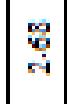 & 望 & 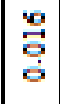 & 苞 \\
\hline
\end{tabular}


جدول رقم (9): التحليل الاحصائي لكمية وقيمة الواردات لمحاصيل القمح والفول البلدي وينجر السكر خلال الفترة (2015-2000)

\begin{tabular}{|c|c|c|c|c|c|}
\hline النمو\% معل & ف & 2 & المعادئة & الوحدة & البيان \\
\hline 4,7 & $* * 13,4$ & 0,49 & $\begin{array}{l}\text { لوص^ه = 8,293 + 0,047 س هـ } \\
\text { ** * (3,7) }\end{array}$ & كمية الواردات & \multirow{2}{*}{ القمح } \\
\hline 12,3 & $* * 82,2$ & 0,85 & $\begin{array}{l}\text { لوص^ه = 6,234 + 0,123 س هـ } 19,1) \\
\text { ** (9,1) }\end{array}$ & قيمة الواردات & \\
\hline 11,3 & $* * 194,7$ & 0,93 & 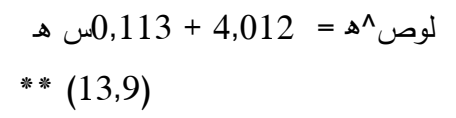 & قيمة الواردات & \multirow{2}{*}{ الفول البلادي } \\
\hline 1.2 & $* 7.53$ & 0.35 & $\begin{array}{l}\text { لوص^ه = } 4.005 \text { + } 0.012 \text { س هـ } \\
\text { * } 2.74)\end{array}$ & نسبة واردات الفول & \\
\hline 11,9 & $* * 89,2$ & 0,86 & 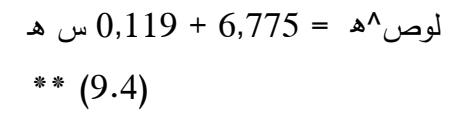 & \multicolumn{2}{|c|}{ قيمة واردات الحبوب } \\
\hline 10,1 & $* * 140,6$ & 0,91 & $\begin{array}{l}\text { لوص^ه = 4,612 + } 0,101 \text { س هـ } \\
\text { *** (7,9) }\end{array}$ & \multicolumn{2}{|c|}{ قيمة واردات البقوليات } \\
\hline 18 & $* * 51.10$ & 0.79 & لوص^هـ = 3.94+ 0.18س هـ & \multicolumn{2}{|c|}{ قيمة واردات السكريات } \\
\hline
\end{tabular}

المصدر: حسبت من جدول رقم (7).

فدان أي أنه يمكن استقطاع مساحة تبلغ حوالي

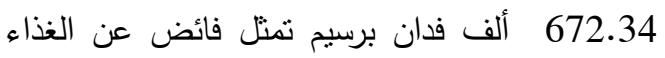

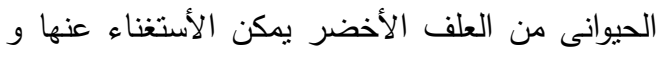
الاستفادة بها وتوجيهـا لزراعة محاصيل الدراسة.

2-تقير المساحات المطلوب زراعتها من محاصيل الاراسة: باستعراض البيانات الواردة بجدول رقم (11)

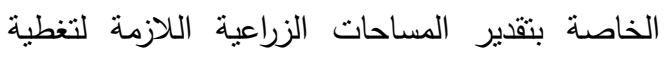
الواردات من أهم المحاصيل الإستراتيجية عام الغراصية 2015

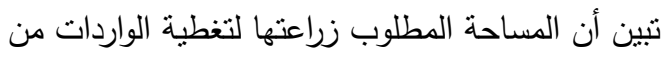
كل من القمح، الفول البلدي، وبنجر السكر بلغت حوالي 3242.5، 192.1، 2015

.2015
رابعاً: تقدير المساحات المطلوب زراعتها من محاصيل الاراسة وفقاً للإحتياجات الفعلية 2015: للثروة الحيوانية في مصر عاميل 1-تقلير الإحتياجات الفعلية للثروة الحيوانية: تبين من فصرات جدول رقم (10) أن إجمالي الوحدات الحيوانية في الزراعة المصرية عام 2015 بلغ حوالي 11.27 مليون إندان وحدة حيوانية نقدر احتياجاتها من الأعلاف الخضراء للموسم الثتنوي بحوالي 18.8 مليون طن بلزم إنتاجها من مساحة برسيم مقدارها حوالي 625.6 ألف فدان على أساس أن منوسط إنتاج الفدان من البرسيم هو 30

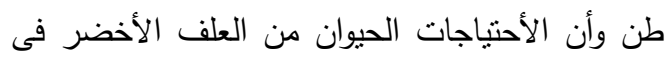
السنة تقدر بنحو 3.33 طن، فى حين تقدر الاحتياجات

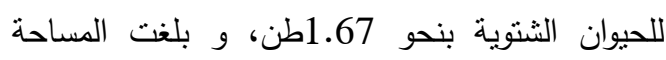
الفعلية المنزرعة في نفس العام حوالي 1297.9 ألف ولف 
Suggested alternatives for winter crop rotation to fill the gap of the

جدول رقم (10): تقدير احتياجات الحيوانات المزرعية من الأعلاف الخضراء للموسم الشتوي 2015

\begin{tabular}{|c|c|c|c|c|c|}
\hline 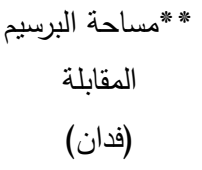 & 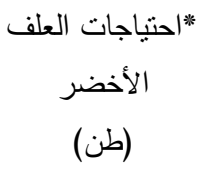 & $\begin{array}{c}\text { (الوحدة الحيوانية) } \\
\text { (الحيوانية } \\
\text { الوحدات }\end{array}$ & معامل التحويل & $\begin{array}{c}\text { عدد الرؤوس) } \\
\text { (رأس) }\end{array}$ & البيان البيان \\
\hline 271017.4 & 8130521.3 & 4883196.0 & 1 & 4883196 & أبقار \\
\hline 256795.7 & 7703869.7 & 4626948.8 & 1.25 & 3701559 & جاموس \\
\hline 30320.6 & 909617.6 & 546316.9 & 0.1 & 5463169 & أغنام أغنام \\
\hline 15719.6 & 471589.0 & 283236.7 & 0.07 & 4046238 & ماعز \\
\hline 6348.6 & 190456.9 & 114388.5 & 0.75 & 152518 & جمال \\
\hline 40300.3 & 1209008.1 & 726131.0 & 0.5 & 1452262 & حمير ل \\
\hline 4035.3 & 121060.5 & 72709.0 & 1 & 72709 & خيول \\
\hline 1020.7 & 30621.8 & 18391.5 & 0.75 & 24522 & بغال \\
\hline 625558.2 & 18766745.0 & 11271318.3 & & 19796173 & ل \\
\hline
\end{tabular}

* تقدر احتياجات الوحدة الحيوانية بنحو 3.33 طن أعلاف خضراء، في السنة. * قدرت علي أساس منوسط إنتاج الفدان من البرسيم حوالى 30 طن. المصدر: 1- أحمد كمال أبو رية، تغذية الحيوان والدواجن، الأسس العلمية الحديثة والعلائق والأعلاف، دار المعارف، الطبعة الثانية، القاهرة، 1969.

3- جمعت وحسبت من وزارة الزراعة، قطاع الثشئون الاقتصادية، نشرة الثروة الحيوانية، عام 2015.

جدول رقم (11): تقدير المساحات الزراعية اللازمة لتغطية الواردات من أهم المجموعات الغذائية

\begin{tabular}{|c|c|c|c|c|c|c|}
\hline 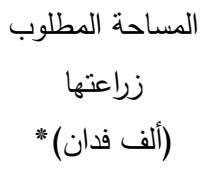 & كمية الواردات & 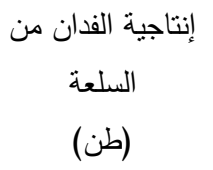 & الاستخلاصبة & 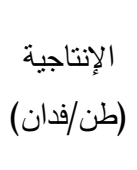 & (ألف فذان) & الاستراتيجية \\
\hline 3242.5 & 8981.78 & - & - & 2.77 & 3468,9 & القمح \\
\hline 192.10 & 278.54 & - & - & 1.45 & 81.93 & الفول \\
\hline 319.99 & 967.21 & 3.023 & 14 & 21.59 & 554.64 & بنجر السكر \\
\hline
\end{tabular}

"المساحة المطلوب زراعتها = كمية الواردات من السلعة / إنتاجية الفدان من السلعة

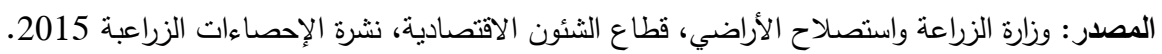


حوالي 2210.13 مليون دولار بحوالي 588.11 مليون دولار أب بنسبة 26.6\% وفقاً لأسعار عام 2015. البديل الثاني: يستهدف تحقيق الإكتفاء الذاتي من محصول الفول البلاي ورفع نسبة الإكتفاء الذاتي من القمح لئح على حساب مساحة محصول البرسيم، حيث يلزم لتحقيق

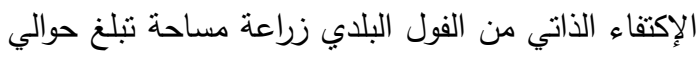

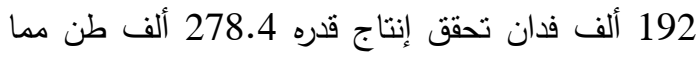
يترتب عليه تحقيق فائض يقدر بحوالي 89 ألف طن

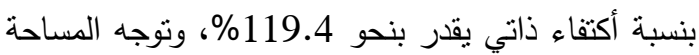

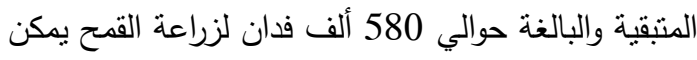
أن تتنج حوالي 63.91 1.61 مليون طن لترتفع نسبة الإكتفاء

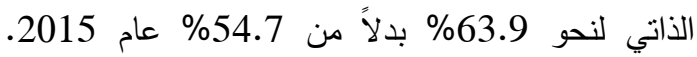

خامسا: البدائل المقترحة للتركيب المحصولي الثتوي وآلية تنفيذها:

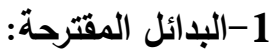

البديل الأول: يستهدف رفع نسبة الإكتفاء الذاتي من

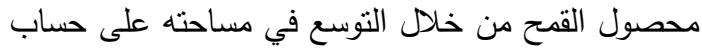
مساحة محصول البرسيم بعد تقدير الاحتياجات العلفية

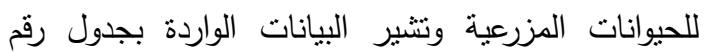
(12) البديل المقترح يترتب علية زيادة في إنتاج محصول القمح تقدر بحوالى 1.86 مليون طن، ليرتفع الإنتاج الكلي

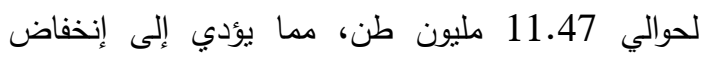
الفجوة الغذائية وزيادة نسبة الإكثاء الذاتي لتبلغ نحو لإنا 65.3 بدلأ من 54.7\% عام 2015، كما تساهم هذه الزيادة في خفض الواردات الزارعية من القمح والبالغة

جدول رقم (12) البدائل المقترحة لمحاصيل العروة الثتوي لعام 2015/2014

\begin{tabular}{|c|c|c|c|c|c|c|c|c|c|}
\hline \multicolumn{7}{|c|}{ المحصول البديل } & \multirow{3}{*}{ المقترحة البئل } & \multicolumn{2}{|c|}{$\begin{array}{c}\text { المحصول الأساسي } \\
\text { (البرسيب) }\end{array}$} \\
\hline \multicolumn{2}{|c|}{ نسبة الإكتفاء } & \multicolumn{2}{|c|}{ قيمة المحصول } & \multirow{2}{*}{ 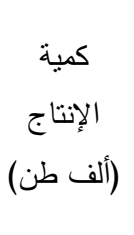 } & \multirow{2}{*}{ فألفاحة } & \multirow{2}{*}{ المحصول } & & \multirow{2}{*}{ المقترحة } & \multirow{2}{*}{ 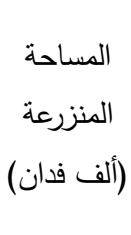 } \\
\hline المقترحة & الحالية & مليون & مليون جنيه & & & & & & \\
\hline 65.3 & 54.7 & 588.11 & 5216.5 & 1862.38 & 672.34 & القـح & البأول & \multirow{6}{*}{672.34} & \multirow{6}{*}{1297.89} \\
\hline 63.9 & 54.7 & 498.7 & 4423.5 & 1606.6 & 580 & القمح & & & \\
\hline 119.4 & 25.62 & 280.74 & 2490.18 & 278.4 & 192 & الفول & الثاني & & \\
\hline 119.4 & 25.62 & 280.74 & 2490.18 & 278.4 & 192 & الفول البدي & \multirow{3}{*}{ البالث الثالث } & & \\
\hline 106.94 & 77.12 & 505.32 & 4482.2 & 6912 & 320 & بنجر & & & \\
\hline 57.22 & 54.7 & 137.57 & 1220.3 & 443.2 & 160 & القمح & & & \\
\hline
\end{tabular}

متوسط سعر صرف الدولار عام 2015 حوالى 8.87 جنيه. المصدر : جمعت وحسبت من وزارة الزرعة واستصلاح الأراضى، نشرة الإحصاءات الزراعية، عام 2015. 
العلمية الحديثة والعلائق والأعلاف، دار المعارف، الطبعة الثانية، القاهرة، .1969

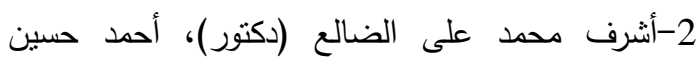
الغنيمى (دكتور)، تحليل وقياس الكفاءة الإقتصادية باستخدام الموارد الإنتاجية الفدانية لمحصول القمح بأهم محافظات الوجة البحرى، مجلة الاقتصاديين

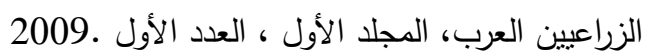
3-الأمم المتحدة، الجمعية العامة، تعزيز حقوق الإنسان وحمايتها : مسائل حقوق الإنسان "الحق في الغذاء، الدورة السادسة والستون، 4 أغسطس 2011. 4-الحسينى أحمد الحسينى النفيلي، رسالة دكتوراه، دراسة والة اقتصادية قياسية للمحاصيل السكرية بمحافظتى كفر الثيخ والمنيا، قسم الاقتصاد الزراعي، كلية الزراعة، جامعة كفر الثيخ، .2010 https:II comtrade.un.org الموقع الإلكترونى

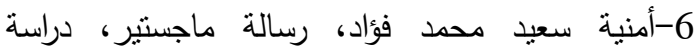
اقتصادية لإنتاج وتسويق بنجر السكر في محافظة الثرقية، قسم الاقتصاد الزراعي، كلية الزراعة، جامعة الزقازيق، .2010 7-وزارة الزراعة واستصلاح الأراضي،قطاع الشئون

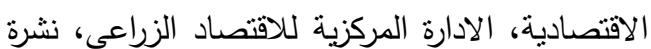

الاقتصاد الزراعى، القاهرة، أعداد متفرقة. 8-وزارة الزراعة واستصلاح الأراضي،قطاع الشئون الشئون الاقتصادية، نشرة الاحصاءات الزراعية،الادارة

المركزية للاقتصاد الزراعى، أعداد متفرقة. 9-وزارة الزراعة واستصلاح الأراضي،قطاع الشئون الاقتصادية، نشرة الميزان الغذائي،الادارة المركزية

للاقتصاد الزراعى، أعداد متفرقة. 10-وزارة الزراعة واستصلاح الاراضي،قطاع الشئون الاقتصادية ، نشرة الاحصاءات الزراعية - الجزء الأول ، القاهرة ، عام 2015/2014 .

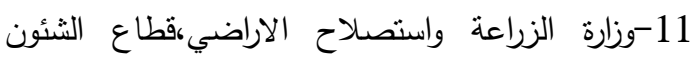
الاقتصادية، نشرة الاحصاءات الزراعية - الجزء الثانى، القاهرة ، عام 2015/2014 . 12-وزارة الزراعة واستصلاح الأراضي، قطاع الشئون الاقتصادية، نشرة التجارة الخارجية، 2015.
البديل الثالث: بستهدف تحقيق الإكتفاء الذاتي من الفول البلدي والسكر ورفع نسبة الإكتفاء الذاتي من القمح على حساب مساحة محصول البرسيم، من خلال الإبقاء علي مساحة محصول الفول البلدي كما هو في البديل الثاني، ويلزم لتحقيق الإكتفاء الذاتي من السكر زراعة مساحة 320 ألف فدان من بنجر السكر لتحقق إنتاج 966.4 ألف طن سكر(نسبة استخراج السكر من بنجر السكر 14\%) لترتفع نسبة الإكتفاء الذاتي لنحو 106.94\% بدلاً من 77.12\% عام 2015، وتوجيه المساحة المتبقية من البرسيم لزراعة محصول القمح والبالغة حوالي 160 ألف فدان تتتج حوالي 443.2 ألف طن لترتفع نسبة الإكتفاء الذاتي لنحو 57.22\% بدلاً من 54.7\% عام 2015. 2-آلية تنفيذ البدائل: لضمان نجاح التركيب المحصولي المقترح فإما أن نتدخل الدولة في الثراء المباشر من المزارع عن طريق تحديد سعر الثراء وفقاً للأسس السن العلمية الدقيقة مما بشجع المزارع على بيع محصوله للاولة، أو تتدخل الدولة بشكل غير مباشر من خلال

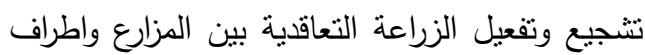
الشراء المختلفة (الهيئات والمنظمات والثركات التسويقية والتصديرية والتصنيعية).

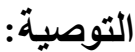

توصى الدراسة بضرورة تفعيل دورالزراعة التعاقدية بوصفها نموذجاً للشراء المباشر (بدون وسيط) بين المزارع والجهات المتعاقدة آلية ناجحة للوصول لسعر عادل مرضي للمزارع ومن ثم فإنها تعنبر حلاً مربحاً لكل من أطراف التعاقد، ولنجاحها بنبغى أن تلتزم الدولة بعدة واجبات من شأنها تحقيق اقصى استفادة من الموارد المتاحة وضمان توافر سبل انصاف فعالة بين أطراف التعاقد، وكذلك ثقديم المساعدة التقنية للمزارعين من خلال خدمات الإرشاد الزراعي العامة، وأن تكفل سبل الحصول على ائتمان موثوق به ومضمون لصغار المزراعين (3). المراجع: - (اجع 1-أحمد كمال أبو رية، تغذية الحيوان والدواجن، الأسس 


\title{
SUGGESTED ALTERNATIVES FOR WINTER CROP ROTATION TO FILL THE GAP OF THE MOST IMPORTANT STRATEGIC CROPS IN EGYPT
}

\author{
Ghada S. Hassan and Safaa M. El-Wakeel \\ Agricultural Economics Research Institute
}

\begin{abstract}
Despite the increase in the production of the most important strategic crops in recent years, this increase is not commensurate with the increasing population needs. The research aimed to increase the production of wheat, faba bean and sugar beet crops as one of the most important strategic winter crops by developing a proposed alternative Of the winter crop composition in Egypt, with a mechanism that allows farmers to increase the cultivated area of these crops at the expense of the alfalfa crop in the agricultural cycle, by studying the indicators of production and consumption, economic indicators, quantity and value of imports of study crops, As well as the estimation of the areas required to grow the crops of the study according to the actual needs of livestock, nd to study the proposed alternatives for winter crop composition and the mechanism for its refinement in 2015.
\end{abstract}

The research has reached a number of important results:

1-The annual growth rate of local production was estimated to be $2.8 \%, 8.3 \%$ and $10.8 \%$ respectively, respectively. The annual growth rate of local production increased by $2.8 \%$, $8.3 \%$ and $10.8 \%$ respectively, The increase in the food gap for both wheat and faba bean was shown at an annual growth rate of $5.1 \%$ and $9.8 \%$, while the change in the sugar beet yield gap was not significant. Individual consumption of wheat, Estimated at 1.5\%, 3.2\%, $3.6 \%$ respectively.

2- The net yield of wheat, faba bean and sugar beet increased at an annual growth rate of $11.9 \%, 11.5 \%$ and $14.4 \%$, respectively. The statistical significance of the rate of return on the invested pound and the rate of return on the costs of the crops under study The value of imports of cereals, legumes and sugars increased at an annual growth rate of $11.9 \%, 10.1 \%$ and $18 \%$ during the study period. The value of imports of wheat, domestic beans increased by an annual growth rate of $12.3 \%$ and $11.3 \%$, respectively. Change in the value of sugar beet imports during the study period.

3- In estimating the actual needs of livestock in 2015, it was found that the total animal units amounted to about 11.27 million animal units whose needs of green fodder for the winter season is estimated at 18.8 million tons. It is necessary to produce an area of about 625.6 thousand feddans. All wheat, municipal beans, sugar beet turned out to be about 3242.5, 192.1, 319.99 thousand acres according to 2015

4-The first alternative is to raise the self-sufficiency rate of the wheat crop by expanding its area at the expense of alfalfa after estimating the feed needs of the farm animals. This led to increasing the self-sufficiency ratio of the wheat crop to about $65.3 \%$. The second alternative achieve self-sufficiency of the bean and raise the self-sufficiency ratio of wheat to about $63.9 \%$. While the third alternative is to achieve self-sufficiency of local beans and sugar and raise the self-sufficiency ratio of wheat at the expense of alfalfa crop area. Increasing the self-sufficiency ratio of wheat and sugar beet to about $57.22 \%$ and $106.94 \%$ respectively.

Key words: Alternatives, winter crops 
Menoufia J. Agric. Economic \& Social Sci. Vol. 2 October (2017): 457 -475 